\title{
BHV-1: New Molecular Approaches to Control a Common and Widespread Infection
}

\author{
Lauretta Turin, Silvia Russo, and Giorgio Poli \\ Institute of Veterinary Microbiology and Immunology, University of \\ Milan, Italy
}

\begin{abstract}
Background: Herpesviruses are widespread viruses, causing severe infections in both humans and animals. Eradication of herpesviruses is extremely difficult because of their ability to establish latent and life-long infections. However, latency is only one tool that has evolved in herpesviruses to successfully infect their hosts; such viruses display a wide (and still incompletely known) panoply of genes and proteins that are able to counteract immune responses of their hosts. Envelope glycoproteins and cytokine inhibitors are two examples of such weapons. All of these factors make it difficult to develop diagnostics and vaccines, unless they are based on molecular techniques.

Materials and Methods: Animal herpesviruses, because of their striking similarity to human ones, are suitable models to study the molecular biology of herpesviruses and develop strategies aimed at designing
\end{abstract}

neurotropic live vectors for gene therapy as well as engineered attenuated vaccines.

Results: BHV-1 is a neurotropic herpesvirus causing infectious rhinotracheitis (IBR) in cattle. It is a major plague in zootechnics and commercial trade, because of its ability to spread through asymptomatic carrier animals, frozen semen, and embryos. Such portals of infections are also important for human herpesviruses, which mainly cause systemic, eye, and genital tract infections, leading even to the development of cancer.

Conclusions: This review covers both the genetics and molecular biology of BHV-1 and its related herpesviruses. Epidemiology and diagnostic approaches to herpesvirus infections are presented. The role of herpesviruses in gene therapy and a broad introduction to classic and engineered vaccines against herpesviruses are also provided.

\section{Introduction}

Herpesviruses have recently become a major subject in virology. They cause widespread infections whose main feature is the establishment of latency. This trait makes it very difficult to eradicate herpesviruses, because no therapies or vaccines have been proved to be fully effective against them. Animal herpesviruses may serve as

\footnotetext{
Address correspondence and reprint requests to: Dr. Lauretta Turin, Institute of Veterinary Microbiology and Immunology, Via Celoria, 10-20133 Milan, Italy. Phone: 3902-2361521/2363544; Fax: 39-02-2362775; E-mail: lauretta.turin@unimi.it
}

a valuable model to investigate the immune response of host organisms as well as to design and assay new vaccines against these infectious agents. Vaccine development has been widely investigated in the bovine herpesvirus 1 (BHV-1) model, giving rise to a wide number of publications on the subject. Such a model should be very informative for other herpesviruses-caused diseases, including human ones.

BHV-1 is the causative agent of infectious bovine rhinotracheitis (IBR) in cattle. IBR is widespread all over the world, occurring mainly as an enzootic disease. In most European Community (EC) countries, crowding of livestock in 
large-scale farms often leads to severe outbreaks of respiratory infectious diseases.

Efforts aimed at controlling IBR derive from the economic losses caused by the disease and economic interests relying on commercial trade of breeding animals. Only "IBR-free" animals, frozen semen, or embryos are allowed for international trade. Indeed, most EC countries have stated freedom from IBR as a prerequisite for the import of live cattle, semen, or embryos.

\section{Etiopathogenesis}

Etiology

BHV-1 is the etiologic agent of different clinical syndromes, including in primis IBR. It belongs to a family of neural-targeting herpesviruses (family Herpesviridae, subfamily Alphaherpesvirinae, genus Varicellavirus). Different isolates can be identified by molecular methods, including viral DNA analysis [restriction endonuclease digestion patterns of viral DNA (1-4)], Southern hybridization, and mapping studies (5); traditional methods rely on serological tests (6) and viral antigen characterization. Each herpesvirus isolate can contain many different strains, each being distinguishable from each other by sequencebased methods (7); e.g., Cooper and Los Angeles (LA) are the most common BHV-1 strains in Europe and the United States, respectively (8).

\section{Pathogenesis and Clinical Features}

Clinical steps in the pathogenesis of herpesvirus infections are acute disease, latency, and reactivation. Such viruses are transmitted directly by aerosol or by close contact among infected animals. Indirect transmission may occur via contaminated food or water, or semen for artificial insemination. The potential portals of entry are the nasal cavity, oropharynx, eyes, and genital tract. Normally, the first round of viral replication takes place in the epithelial cells at the portal of entry. The symptoms of the acute disease restricted to local areas (the upper respiratory tract and eyes) are mainly associated with destruction of infected epithelial cells caused by virus replication. The highest virus titers are produced and excreted at this stage of infection. These infections are usually self-limiting, thanks to a prompt immune response, and recovery usually takes place within 1 to 2 weeks. Local lesions, however, may facilitate secondary bacterial infec- tions, causing more severe damage, such as pneumonia.

The virus may spread in the infected host by viremia, gaining access to a broader range of tissues and organs and causing a variety of diseases-e.g., abortion and enteritis are the most serious consequences of BHV-1 infections. Furthermore, the virus can enter nervous cells, establishing a latent infection in sensitive ganglia. It is not yet clear whether the infection of the central nervous system (CNS) by herpesviruses is achieved via axonal transport (during its initial replication at the portal of entry, the herpesvirus may enter the axons of local nerve cells) or via viremic spread (9).

Clinical symptoms of infection with herpesviruses are characterized by a large variability in severity: they may be mild and localized or they may include severe generalized illness, leading in some cases to death or, in contrast, going unnoticed. The pathology of BHV-1-caused diseases is largely due to respiratory infection; after a primary infection, virus replicates in epithelial cells of the high respiratory tract, causing necrosis. In some cases, BHV-1 can propagate itself in the organism by a systemic route or to the lungs, inducing a bronchopneumonia often complicated by secondary bacterial superinfections (10). During primary infection, when virus is replicating intensively, a large amount of viral particles is present in nasal exudates; the infected animals are highly contagious to others in their surroundings.

In cattle, clinical symptoms of the respiratory disease are the following: after 2 to 6 days, pyrexia, reduced appetite (anorexia), dyspnoea (increased respiratory rate), cough, bilateral nasal discharge, and depression occur, often accompanied by conjunctivitis and mucopurulent ocular secretions. Auscultation reveals the presence of a tracheitis. Animals recover within 2 weeks, except when bacterial superinfection occurs (in approximately $10 \%$ of the affected animals). In this case, bronchopneumonia can cause death.

Infections of the genital tract are frequently caused by artificial insemination practice. The minimal dose to infect a cow by artificial insemination has been estimated to be 32 infectious viral particles. In males, preputial and penile mucosae seem to be the tissues of the male genital tract supporting BHV-1 replication (11). Clinical signs vary from mild to severe balanoposthitis and may be associated with a decrease in semen quality (reduced motility and morphological abnormalities of sperm cells) (12). Because semen 
is usually contaminated with virus from preputial and penile mucosae, seminal plasma rather than sperm cells contains the virus.

In females, infection may lead to infertility disturbances, mainly endometritis (13). The risk of transmitting BHV-1 to inseminated cows by using BHV-1-seropositive bulls for artificial insemination is substantially reduced by preadsorption of semen (14) and by testing semen batches. When IBR develops in a herd that includes pregnant cattle, abortions may occur after 3 to 6 weeks post infection, mainly between the 5 th and 8th month of pregnancy. Under field conditions, about $25 \%$ of pregnant cattle undergo abortion after an outbreak of IBR (15).

Calves can also become infected at and after birth. Cows suffering from acute infection can infect newborns directly in the uterus, through a systemic route, or via contaminated nasal secretions. Parturition is associated with increased blood levels of glucocorticoids; also, labor constitutes a stress in and of itself, adding to the endocrine status. Physiologically, parturition represents a risk situation that might result in bovine rhinotracheitis virus reactivation and/or, re-excretion. It is well established that latent IBRcausing virus can undergo reactivation by both stressing conditions or administration of glucocorticoids (16).

\section{Epidemiology and Diagnosis}

Epidemiology

IBR is considered a species-specific cattle disease. Other animal herpesviruses, strictly related to BHV-1, cause similar diseases in pigs, goats, minks, and ferrets. Human herpesviruses are responsible for systemic, eye, and genital infections, in both children and adults. Some herpesviruses have been related to tumor onset, e.g., Burkitt's lymphoma, and nose-pharyngeal carcinoma.

BHV-1 comes in contact with herds mainly through introduction of new animals, either in the acute phase of a primary disease or when latently infected. As illustrated in Figure 1, even semen from infected bulls and infected embryos are suitable viral carriers. Once the virus enters a herd, it is mainly spread by direct contact between animals (through respiratory, ocular, or genital secretions). An indirect route of spread is also possible, by means of contaminated instruments. Since Switzerland and Denmark succeeded in BHV-1 eradication, attention has been focused on virus eradication in the other EC countries. Presently, a number of countries have entered eradication programs. In the countries where BHV-1 infection has a high prevalence, eradication is only economically feasible by preventing new infections while increasing the culling of infected animals. Awareness of epidemiological risks and improvement of management both play an important role in limiting or even avoiding viral spread within and between herds (17). A hallmark of the herpesvirus biological cycle is its ability to establish latent, life-lasting, and periodically reactivating infections in the host. It is the most harmful herpesvirus property, which makes the use of semen from BHV-1seropositive bulls or embryos a major concern. Bulls, once infected, must be regarded as lifelong potential BHV-1 sources. In fact, BHV-l spreads along the nerves to the sympathetic ganglia, where it remains latent for life (11), until a proper stimulus induces its reactivation (18). Several conditions that are common in livestock breeding are quite stressful, making cattle prone to bacterial and viral infections as well as to herpesviruses reactivation. These include increased levels of corticosteroids, pregnancy, transport, entrance into a new herd, concomitant viral or bacterial infections, poor management conditions, and deficient diet.

In bovine species, transport of the virus is associated with an increase in corticoid blood level; thus virus-carrying animals are simultaneously submitted to stressful conditions. Transport is indeed responsible for reactivation of IBR virus. BHV-1 re-excretion and rise in neutralizing antibodies are direct and identifiable indicators of reactivation (19).

Other stressful situations may play an important role in BHV-1 infection of cattle-e.g., coinfection with other pathogens, such as bovine immunodeficiency-like virus (BIV) (20). Inadequate diet and mineral deficiency may also affect acutephase reactivation of BHV-1 infection (21).

Much of the dynamics of BHV-1 infection, however, is unclear-i.e., how long BHV-1 can circulate in a herd, whether all susceptible animals become infected, or whether circulating BHV- 1 is present after all the animals have seroconverted. Knowledge of transmission parameters and population dynamics of BHV-1 under field conditions can give information pertinent to the prevention of viral persistence, avoidance of virus spread, eradication of virus, and protection for the target population (22).

A herd is currently considered IBR-free if 


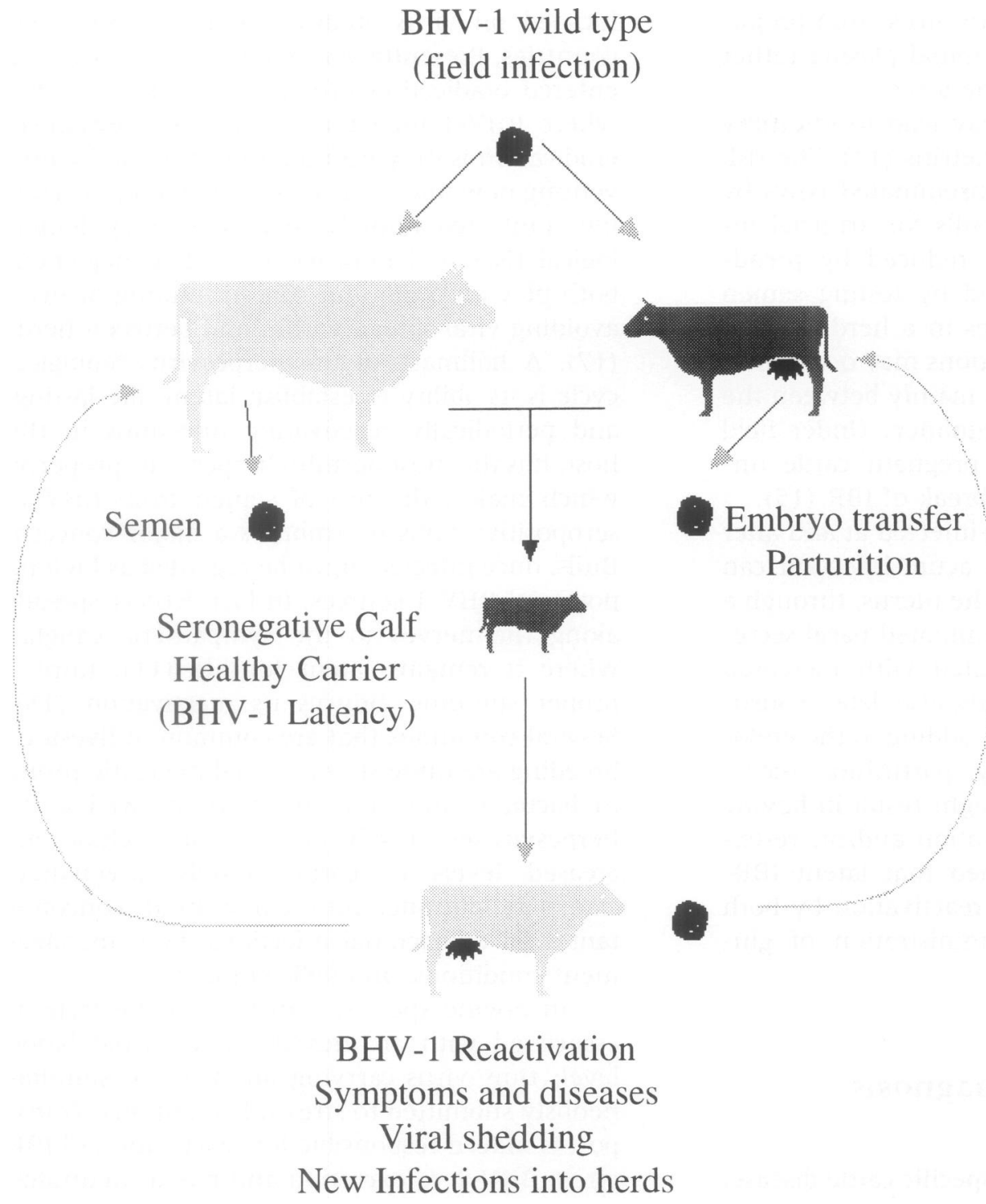

Fig. 1. Epidemiology of BHV-1 infection. The main portals of virus entry are shown. two consecutive serological tests (ELISA) of serum or milk samples give negative results in all animals. Infection-free status can be maintained by ensuring closed management conditions as much as possible. Contact and mixing of a herd with other herds or new animals should be avoided. Artificial insemination must be carried out only with semen from IBR-free sires. To control for infection-free status, all breeding sires and at least $10 \%$ of cows in each herd should be tested for IBR by ELISA every 6 months, and all animals must be BHV-1 negative (23).

\section{Diagnosis}

Sensitive methods of diagnosis, even if followed by an adequate prophylaxis, must take in ac- count the latency that is typical of herpesviruses. Clinical diagnosis can be carried out in acute herpesvirus infections, but laboratory tests are required for detection of latent virus (18). In such conditions, latent virus can be only detected in sensory nervous ganglia, e.g., trigeminal ganglia after respiratory infection or sacral ganglia after genital infection by co-cultivation techniques (24) or by in situ hybridization (25). Current methods of analyzing herpesviruses in diagnostic virology laboratories include virus isolation, immunofluorescence staining of tissues by specific antibodies, and serological tests. Molecular methods, based on nucleic acid analysis, are undoubtedly the most sensitive and effective for determining latent infections, but these methods are not yet widely practiced. 
Isolation of herpesvirus is a laborious procedure, has a long turnaround time, and requires processing of samples within $24 \mathrm{hr}$ after their collection (26). Moreover, some tissues contain enzymes that are toxic for cultured cells or viral inhibitors, thus interfering with virus isolation procedures (27). Typical examples are toxic components hindering viral detection in semen. Several pretreatment methods such as kaolin adsorption and centrifugation steps have been developed, but simply diluting semen before inoculating cell cultures has seemed to give the best results $(27,28)$. In vitro lymphoproliferative assay is not reliable in detection of virus in animals latently infected or immunized (29).

Serological tests (ELISA, passive hemoagglutination, viral neutralization) have been used to detect specific antibodies against BHV-1 or specific viral antigens (30-33). More recently, single BHV-l glycoproteins (gI, gIII or gIV) expressed by baculovirus have been shown to be potential diagnostic antigens for detection of anti-glycoproteinspecific antibodies in ELISA, Western blot, and dot blot assays (34). But serological tests are generally time-consuming and lack sensitivity, allowing false-negative results. Moreover, standardization of methods across different laboratories is necessary to ensure recognition of seropositive subjects with low-antibody titers (35). Methods based on fluorescent antibodies require a large number of virusinfected cells and often autofluorescence can mask the specific immunofluorescence (36).

More specific procedures, based on various types of DNA probes, have been used in dot-blot hybridization assays to detect herpesviruses genome $(37,38)$, but these methods usually lack sensitivity too. Polymerase chain reaction (PCR)-based assays have been successfully developed, showing high sensitivity for latent infections and virus in semen (39). Different PCR strategies have been successfully carried out to amplify target regions ( $t k$ or glycoproteins genes) of herpesvirus genome (40-46). Combined molecular approaches also provide methods of differentiating between viral subtypes, which is valuable for assessing organ tropism and epidemiological status (47).

Virological and serological examinations have shown the importance of various other viruses as initiative agents during the acute phase of the disease. Secondary bacterial infections may lead to chronic pneumonia. Chlamydia, Mycoplasma, Streptococcus, Corynebacterium, and Klebsiella are frequently occurring agents; e.g., severe lesions caused by Pasteurella haemolitica and/or Pasteurella multocida (48) are in concomitance with BHV-1 infections.

\section{Molecular Approaches}

Structure of Viral Particle

BHV-1 virion is surrounded by a lipidic envelope, bearing a number of virus-encoded glycoprotein spikes. These glycoproteins are thought to mediate several key steps during the early stages of infection, including viral attachment and penetration into the host cell. Later during infection, newly synthesized viral glycoproteins are also present on the surface of infected cells (Fig. 2).

\section{Envelope Glycoproteins and Their Role in BHV-1 Infection}

Herpesviruses have a number of genes encoding glycoproteins; the corresponding gene products range from 15 to $>100 \mathrm{kDa}$. They are often $\mathrm{N}$ - or O-linked to oligosaccharides and they can form homo- and heterodimers. Most BHV-l glycoproteins are homologous in function and structure to those specified by herpes simplex virus type 1 (HSV-1) (49). Because of the striking similarity between animal and human herpesviruses, BHV-1 may serve as an excellent model for analyzing the structure and life cycle of herpesviruses. Because of their location in the viral envelope and on the surface of infected cells, glycoproteins are important targets for host immune response. Some glycoproteins are necessary for replication in cell culture (49); their main features are presented in Table 1.

Herpesvirus glycoproteins (gI, gIII, and gIV) are involved in several steps of viral replication: they are responsible for the initial attachment of the virus to the cellular receptor and the subsequent penetration of the host cell; they account for the tropism of the virus for tissues and organs; and they are involved in envelopment of the capsid, viral egress and transmission of infection by cell-to-cell spread (50-52). Some glycoproteins are receptors for the Fc fraction of immunoglobulins-e.g., gI and gE are predicted to form a FC receptor, whereas $\mathrm{gC}$ has been shown to bind complement factor $\mathrm{C} 3 \mathrm{~b}(49,53)$. The initial attachment of herpesviruses to permissive cells is mediated by an interaction of gIII molecules with cellular glycosaminoglycan heparinsulfate through heparin-like receptors (54).

Recently, the existence of multiple alphaherpesvirus co-receptors that interact with gIII and 


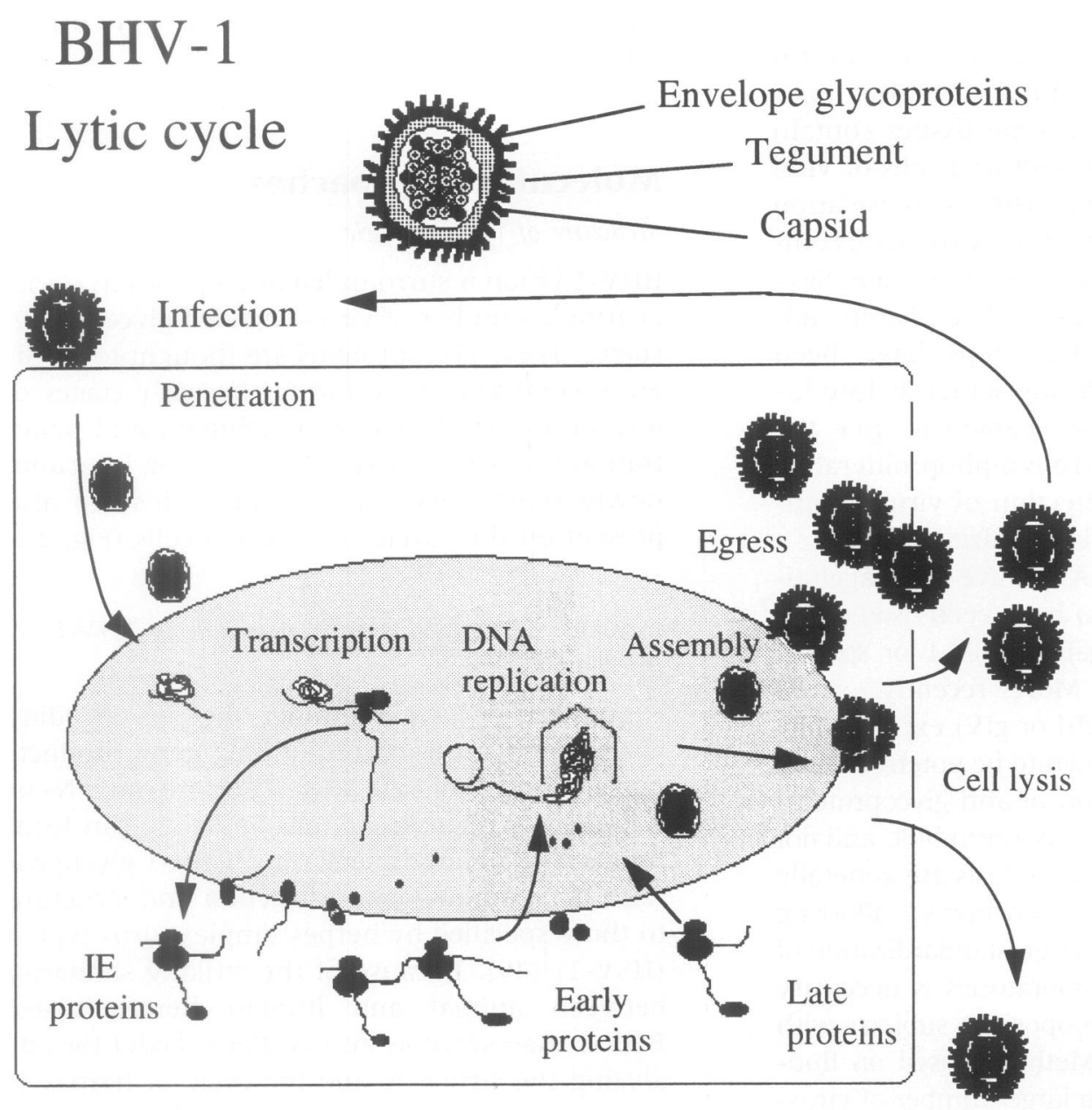

Fig. 2. BHV-1 particle structure and lytic cycle.

mediate herpesvirus entry has been shown. Two of them have been already identified and are called herpesvirus entry mediators A and B (HveA and HveB). Their role and the bindingentry mechanisms are being investigated (55). HveA, a protein belonging to the tumor necrosis factor (TNF) receptor family, is the major receptor for the entry of HSV into human lymphoid cells, but not into other cell types (56). HveB is a secondary receptor for HSV-1, corresponding to poliovirus receptor-related protein 2; it fails to mediate the entry of wild-type HSV-1 or BHV-1 strains, showing that multiple alphaherpesvirus co-receptors may exist, differing in their specificity toward individual viruses in the superfamily.

Glycoproteins are also involved in virus attachment, which is a complex event where highaffinity receptors play a critical role (57-59). gH and gL are necessary for fusion between the virion envelope and cell membrane (60). Although herpesvirus polypeptide synthesis is temporally controlled ( $\alpha$, or immediate early; $\beta$, or early; and $\gamma$, or late genes) the kinetics of virus replication is actually very rapid following attachment and entry into the cell $(61,62)$.

BHV-1 gIII is a homodimer protruding from the viral envelope where it works as a major viral attachment protein $(63,64)$. It serves as a general membrane anchor to mediate virus attachment to permissive cells, thus participating in the penetration process (65). gIII in particular is responsible for heparin-binding, which is an important herpesvirus mechanism of attachment to permissive cells. In fact, some herpesviruses, e.g., HSV-1 and BHV-1, initially attach to cells through binding to heparin-like moiety on the plasma membrane (66).

\section{Regulation of Lytic and Latent Infection}

Viral Genome and Its Regulation

The herpesvirus genome is a linear, doublestranded DNA (dsDNA) molecule ranging from 120 to $230 \mathrm{~kb}$ in size. Its structure consists of a 
Table 1. Glycoproteins of BHV-1

\begin{tabular}{|c|c|c|c|c|c|c|c|c|}
\hline Protein & Gene & Location & & ID & MW & Gly & Function & Reference \\
\hline $\mathrm{gI}=\mathrm{gB}$ & UL27 & $e n v$ & $\mathrm{E}$ & + & $\begin{array}{l}1307455 \\
(101)\end{array}$ & $\mathrm{N}$ & $\begin{array}{l}\text { Heterodimer } \\
\text { Binding to heparin-like factors } \\
\text { Attachment, entry, fusion, cell to } \\
\text { cell spread }\end{array}$ & 72,57 \\
\hline $\mathrm{gII}=\mathrm{gH}$ & UL22 & $e n v$ & $\mathrm{E}$ & - & $\begin{array}{l}108 \\
(88)\end{array}$ & $\mathrm{N}$ & Entry, cell-to-cell spread, egress & 188,189 \\
\hline $\mathrm{gIII}=\mathrm{gC}$ & UL44 & env & NE & + & $\begin{array}{c}91 \\
(54)\end{array}$ & $\mathrm{N}, \mathrm{O}$ & $\begin{array}{l}\text { Hemagglutinin (virulence factor) } \\
\text { Binding to heparin-like factors } \\
\text { and to } C 3 b\end{array}$ & $54,57,66,190$ \\
\hline$g I V=g D$ & US6 & $e n v$ & $\mathrm{CE}$ & + & $\begin{array}{c}71 \\
(45)\end{array}$ & $\mathrm{N}, \mathrm{O}$ & $\begin{array}{l}\text { Binding to mannose-6-phosphate } \\
\text { receptors } \\
\text { Entry, cell-to-cell spread }\end{array}$ & $\begin{array}{l}57,59,52,50, \\
51\end{array}$ \\
\hline $\mathrm{gE}$ & US8 & env & NE & + & $\begin{array}{c}92 \\
(61)\end{array}$ & $\mathrm{N}$ & $\begin{array}{l}\text { Neuroinvasiveness } \\
\text { Fc receptor (with gI) } \\
\text { Cell-to-cell spread }\end{array}$ & $\begin{array}{l}53,154,173 \\
179\end{array}$ \\
\hline $\mathrm{gX}=\mathrm{gG}$ & US4 & Secreted & $\mathrm{NE}$ & - & $(65)$ & $\mathrm{N}, \mathrm{O}$ & Function unknown & 191,192 \\
\hline gK & UL53 & env & $?$ & - & (35) & $\mathrm{N}$ & Syncytium formation & 193 \\
\hline gI & US7 & $e n v$ & $\mathrm{NE}$ & - & $(40)$ & $?$ & $\begin{array}{l}\text { Neuroinvasiveness } \\
\text { Binding to Fc receptor (with gE) } \\
\text { Cell-to-cell spread }\end{array}$ & 49 \\
\hline gM & UL10 & env & $\mathrm{NE}$ & - & $(43)$ & $\mathrm{N}$ & $\begin{array}{l}\text { Spread in CNS, membrane } \\
\text { penetration }\end{array}$ & 194 \\
\hline gL & ULl & Secreted & $\mathrm{E}$ & - & $(17)$ & $\mathrm{O}$ & $\begin{array}{l}\text { Conserved } \\
\text { Entry, cell-to-cell spread }\end{array}$ & 195 \\
\hline
\end{tabular}

$\mathrm{CE}$, conditional essential (i.e., essential in some conditions only); $\mathrm{E}$, essential; env, envelope; Gly, Glycosylation; ID, immunodominant; MW, molecular weight (unglycosylated MW, kDa); NE, nonessential; N, O, N-linked and O-linked glycans; UL, unique long; US, unique short.

unique long segment (UL), an internal repeat (IR), a unique short segment (US), and a terminal repeat (TR), which is inverted with respect to the IR. A consequence of such a genome structure is the ability to invert the US relative to the $\mathrm{UL}$, leading to two isomeric structures of the DNA molecule $(7,67)$. The biological implications of this inversion are not known.

Large herpesvirus genomes carry many open reading frames (ORFs), coding for a number of structural and regulatory proteins. Viruses belonging to a herpesvirus superfamily share homology in many ways: BHV-1 gI and HSV-I gB share structural homology $(56.3 \%$ nucleotide similarity and $45.9 \%$ amino acid similarity) (68) as well as functional homology (69). gI also shares extensive similarity with gB glycoprotein from pseudorabies virus, varicella-zoster virus, cytomegalovirus (CMV), and Epstein-Barr virus (EBV) (70-72). BHV-1 gIV shares amino acid and functional similarity with HSV-1 and other herpesvirus gD glycoproteins. BHV-1 genome comprises 67 unique genes and 2 duplicated genes in the inverted repeats. Thus, BHV-1 may encode at least 69 proteins.

Glycoproteins, which are mainly expressed on the virus envelope, share a remarkable degree of structural and functional conservation in many herpesviruses, including some that are only distantly related $(70,73)$. The architecture of many genomic regions is strictly conserved within herpesviruses, while similarity varies characteristically from gene to gene (74).

Molecular virology of BHV-1 and other herpesviruses has advanced considerably in the last few years, propelled by genome projects and by inquiries into the functions of key viral proteins. Thanks to international cooperation, the nucleotide sequences of many herpesviruses are now known or close to being completely determined (49). 


\section{Lytic Cycle}

Northern blot analysis shows that herpesvirus genes are transcribed and expressed in a cascade, and are temporally and spatially regulated (75). As shown in Figure 2, immediately after the release of viral genome from the capsid, immediate early (IE) genes are transcribed, producing the alpha proteins. These activate the transcription of early (E) genes and the synthesis of beta proteins. Late-gene (L) activation is delayed; the expression of gamma proteins occurs once the synthesis of virion DNA has been taken up $(62,76,77)$.

The regulation of this process is mediated by genes that are clustered in the inverted repeats and adjacent segments: three major immediate-early proteins, $\mathrm{BICP} 0, \mathrm{BICP} 4, \mathrm{BICP} 22$, circ protein, and the early protein BICP27 have been identified and characterized $(49,78-80)$. These proteins were studied by using various promoter-reporter genes (e.g., CAT gene) in transient expression assays, observing both transactivation and transrepression, depending on the effector protein and the target promoter. The deletion of circ gene allows recombinant virus to live in cell culture (81). Herpesvirus genomes are linear molecules in virions. Upon infection of host cells, the linear dsDNA genome becomes circular, before DNA replication occurs. During viral replication and virion assembly, circular replicative-form genomes undergo specific cleavage in linear unit-length molecules. This is the phase when the inversion of the short segment is most likely to occur (82). Tissue damage caused by herpesvirus infection is due to cell lysis, which takes place once new viral particles are formed and released into extracellular fluids, carrying cells to death.

The circ gene is IE transcripted, once the genome ends are covalently joined (83). Components of virions entering the host cell may trigger the IE phase of the subsequent replication cycle. The late tegument protein encoded by UL48 gene, $\alpha$-TIF, was shown to stimulate the El promoter, resulting in transactivating transcription $(84,85) . \alpha$-TIF is a transactivator that can recruit a homeodomain protein into a transcriptional regulatory complex. It has homeodomain recognition properties and virus-specific cis-regulatory specificities. It activates transcription from the response element. A domain in the response element is responsible for the differential cis-element recognition and transcriptional activation. This demonstrates how, through selective association with homologous but different homeodo- main co-regulators, a single homeodomain protein can direct differential transcriptional regulation (86). The IE proteins are important for the regulation of the productive cycle of herpesvirus replication (87). An auxiliary function in this process was attributed to VP8, the UL47 gene product (88). Alternative splicing is a device for coordinating IE gene expression (89).

\section{Latent Infection}

Latency and reactivation are undoubtedly ways in which herpesviruses adapt to escape host-immune response, yet these are not the only ones. Local spreading through intercellular junctions and intra-axonal transport reduce the need for high amounts of infectious virus. The effectiveness of the humoral immune response is thus reduced, making it easier for virus to spread within the host organism. Herpesviruses use very subtle ways to circumvent the actions of the immune system, as shown by molecular analysis of herpesvirus genes and proteins. For example, gIII can bind to the third complement component $(\mathrm{C} 3)$ in a species-specific manner and this binding destabilizes the $\mathrm{C} 3$ convertase and thus blocks the alternative pathway of the complement system (90). BHV-1 gIII belongs to the immunoglobulin superfamily and is antigenically related to a cell-surface glycoprotein expressed by macrophages and other leukocytes. Therefore, it may evade certain immune functions by molecular mimicry $(63,73)$. Similarly, it is known that $\mathrm{gE}$ and gI build up a complex that acts as an Fc-receptor, preventing normal action of antibodies (91). Major histocompatibility complex (MHC) class I expression is reduced following infection with herpesviruses (92). This may have a major impact on the pathogenesis of the infection, because failure of antigen presentation helps virus to evade detection by cytotoxic lymphocytes. Nevertheless, the most important way for the virus to escape the immune response resides in the establishment of latency. Molecular events leading to and controlling latency are not yet completely understood.

Two conditions have to be fulfilled to allow the establishment of biologically significant latency, i.e., latency that allows the virus to remain in an infected host for long periods of time. First, long-living and therefore nonreplicating, highly differentiated cells, such as neurons and lymphoid cells, are ideal for harboring virus during latency. Second, in sharp contrast to productive infection and replication in peripheral tissues, 


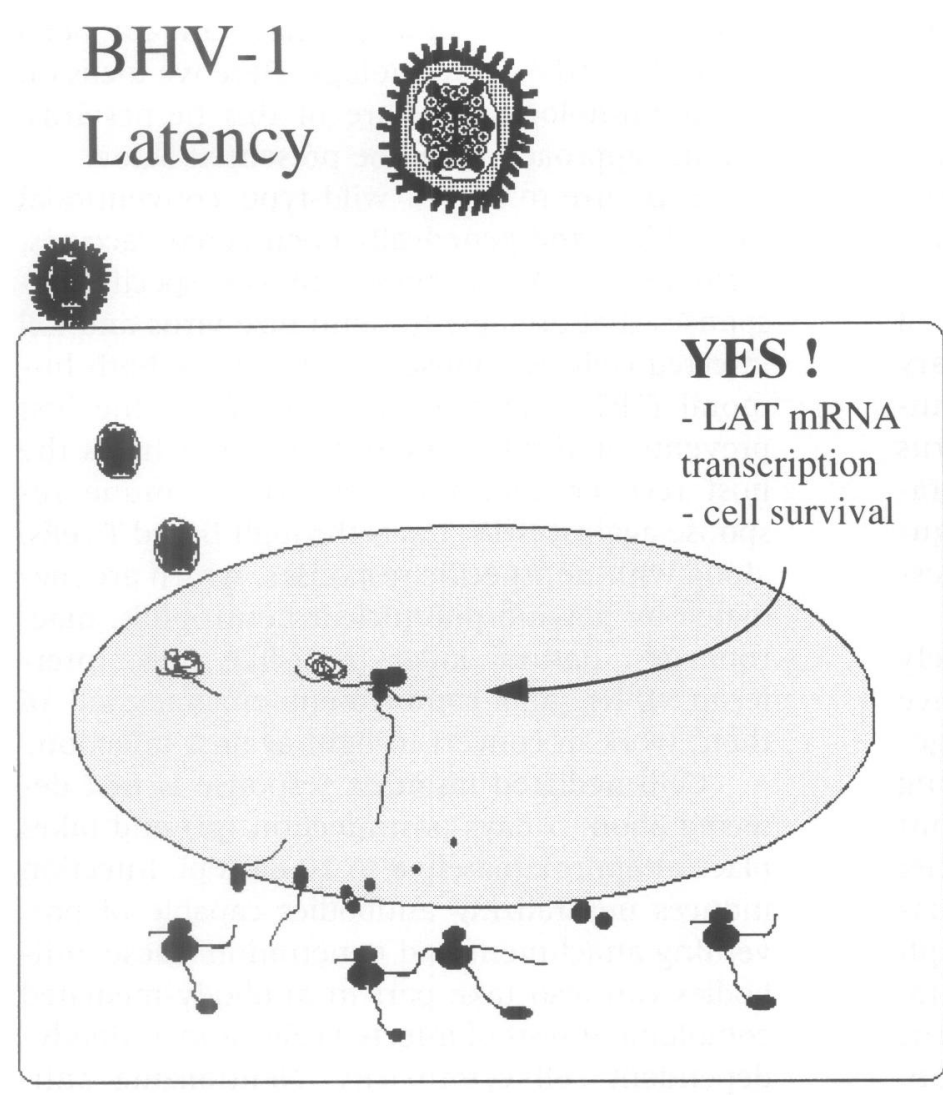

\section{NO!}

- DNA synthesis

- "lytic" mRNAs

- structural proteins

- new viral particles

- cell lysis

Fig. 3. BHV-1 latency cycle. latently infected cells must not be destroyed. Thus, both induction of apoptosis and destruction by immune mechanisms must be prevented. Either no viral protein at all may be newly synthesized during latency, or the protein has to be tolerated by the immune system. Consequently, productive viral replication must be interrupted at an early stage. Only restricted viral transcription has been detected in cells latently infected. The significance of these latency-associated transcripts (LAT) is still under speculation (9).

The latent virus represents the long-term reservoir in an immune host that becomes relevant upon reactivation. Certain conditions of the host or certain stimuli may lead to reactivation from latency and re-excretion. The reactivated BHV-1 is transported intra-axonally back to the periphery, to the original portal of entry, where it is available for transmission to other susceptible hosts. Viral replication in the course of reactivation may cause recurrence of the disease.

During latent infection of neurons, gene expression is strictly limited (Fig. 3). Investigations into the molecular basis of latency have shown that the genome is transcriptionally active in latently infected ganglionic neurons and transcription is restricted to a region containing the promoter and the ORF coding for latency-related (LR) RNA (93). The expression of S-phase regulatory proteins, such as cyclin A, leads to neuronal apoptosis of infected cells. LR gene product (LRP) is a nuclear protein expressed in trigeminal ganglionic neurons of latently infected cattle. It inhibits S-phase entry and blocks cell-cycle progression through binding to cyclin A. Consequently, interactions between LRP and cell-cycle regulatory proteins promote survival of postmitotic neurons during acute infection and/or viral reactivation $(94,95)$. LR promoter has strict orientation preferences in different cell types, indicating that the LR gene of BHV-1 is regulated by tissue- and species-specific transcription factors as well as viral or virus-induced factors $(96,97)$. The unique promoter with detectable activity in latently infected ganglionic neurons is the LAT promoter, which controls transcription of the BICPO gene in the opposite orientation. Such transcripts may encode regulatory proteins or are likely to act by an antisense effect $(93,97,98)$.

Splicing junction sites of LTR were recently identified, suggesting alternative splicing of LTR occurs in acutely infected or latently infected cells. Such a mechanism may give rise to protein 
isoforms endowed with different biological properties (99).

As reported for other herpesviruses, the acute-phase kinetics of BHV-1 gene expression in trigeminal ganglia neurons is similar to the lytic-phase kinetics in non-neuronal cells. Kinetic experiments also show that efficient transcription of IE genes in trigeminal ganglia of cattle does not occur, even during a primary infection (100). Viral enzymes, such as thymidine kinase, although nonessential for virus replication in cell culture, may supply metabolic functions that are normally down-regulated in neurons and thus enable the herpesvirus to come out of hiding (101).

Reactivation is a process that is entirely distinct from establishment and maintenance of latency and through which latent viral genomes enter a new lytic cycle (102). During latency, no viral antigens are synthesized, but genome of latent virus can be found in nuclei of G0 cells in ganglia. Additional sites of latency have been recently shown in lymph nodes and nasal mucosae, which host viral replication (103). Upon reactivation, the virus re-establishes its lytic cycle of replication. Shielded from effector cells of the immune system, it migrates to peripheral tissues, where it is excreted and may be transmitted. Although a strong immune response is provoked in infected organisms during primary replication, herpesviruses have developed several strategies to escape immune surveillance and to establish virus latency in the infected ganglia, thus creating the opportunity to start a new infection under a reactivating stimulus (9).

\section{Immunology of BHV-1}

\section{Immunology of $B H V-1$ Infection}

In order to develop better vaccines against herpesvirus infections and to design live viral vectors, it is crucial we understand the relation between virus and host organism defenses and how the virus escapes them. We need to learn not only how immune responses are involved in recovery from primary and secondary infection but also how the establishment of latency can be prevented and, once it is established, how clinical reactivation and viral spread can be avoided. Natural infections caused by BHV-1 in cattle are a suitable and convenient model to design, develop, and test vaccines against herpesviruses.
Indeed, all current strategies have already been assayed in BHV-1 vaccinology. Here we focus on the immunological picture of this herpesvirus; vaccine approaches will be presented below.

Exposure to BHV-1 wild-type, conventional live, killed, and genetically engineered vaccines, including DNA vaccines, induces specific responses that are able to neutralize virus and kill infected cells. Responses to BHV-1 are both humoral (Th2) and cell mediated (Th1); the first prevents viral infection and the latter helps the host recover after infection. The immune response against BHV- 1 acts through $B$ and $T$ cells, along with nonspecific responses, which are mediated by polymorphonuclear neutrophils, macrophages, natural killer (NK)-like cells, interferon (IFN), and complement enzymes; all of them work in concert to fight against infection.

Cell-mediated immune response is first detected about 5 days postinfection (pi) and takes place at approximately 8 to 10 days pi. Infection induces neutralizing antibodies capable of preventing attachment and penetration; these antibodies can also take part in antibody-mediated complement lysis of infected cells or in antibodydependent cell cytotoxicity. Neutralizing antibodies, mainly IgM, followed by IgG, are usually detected around 10 days after infection. Mucosal immunity also becomes activated, as shown by IgA found in nasal and genital secretions. The virus also induces specific cellular responses including induction of cytokines, which either directly or indirectly inhibit virus replication by activation of effector cells (104). Lymphocytes, NK-like cells, macrophages, and polymorphonuclear neutrophils can kill virus-infected cells either directly, via MHC-I recognition, or by interacting with antibody to induce cell death by antibody-dependent cell cytotoxicity (105). Killing of virus-infected cells occurs after the expression of viral antigens on the surface of infected cells (106).

The relation between the timing of cell killing and completion of virus assembly explains whether the cycle of infection is aborted or productive viral replication occurs. Indeed, any enhancement of viral killing dramatically reduces viral load. The role of antibody is critical in preventing infection and viral spread. Conversely, cell-mediated immunity may help recovery from infection. In most cases the peak activity of these cellular responses occurs at 7-10 days pi (107). The role of most viral proteins is not presently known, except for that of the major glycoproteins, which act as targets for cell-mediated im- 
munity (cell interaction and lysis by NK cells) (106) and that of antibody-activated $\mathrm{CD}^{+} \mathrm{T}$ lymphocytes $(108)$ or $\mathrm{CD}^{+}$cytotoxic lymphocytes (109).

Since all these events can occur at the same time, they mutually reflect each other. Furthermore, the relative importance of each effector mechanism clearly depends on whether the animal is exposed to the virus for the first time (primary infection) or has received a secondary exposure following vaccination or infection with field virus. Following a primary infection, when there are no antibodies interfering with viruscell interaction at the receptor level, initial interaction is mediated by viral glycoproteins. The synthesis of viral proteins then induces a cascade of events, stimulating nonspecific immune responses of the host via induction of early cytokines. Nonspecific immune responses activated by viral products are the first aid to clearing out the infection, both directly and indirectly. Macrophages drive specific immune responses by producing cytokines and subsequently responding to cytokines produced by $\mathrm{T}$ cells to kill virusinfected cells. This activity becomes detectable within 2 days pi in lung parenchymal cells and 3-5 days later in peripheral blood leukocytes. Interactions between various effector functions result in limiting virus replication. Cell-mediated immunity is probably more important in recovery from initial infection, but it works in concert with nonspecific and humoral immune response to ensure rapid clearance of the virus (107).

During the course of an acute viral infection, BHV-1 induces immune suppression through a mechanism that is not yet well identified. BHV-1 is known to down-regulate the expression of MHC class I molecules on the surface of infected cells $(92,93)$. It probably interferes with the protective function of $\mathrm{CD} 8{ }^{+}$ cytotoxic T lymphocytes (CTLs), which are involved in lysis of BHV-1-infected cells (109). Other effector mechanisms are likely to play a role: $\mathrm{CD} 4^{+}$-mediated CTL activity has been proposed as a strategy aimed at providing cellular protection in BHV-1 infection. Stimulation of peripheral blood mononuclear cells (PBMC) of cattle immunized with attenuated live BHV-1 has shown that cytolytic effector cells are primarily $\mathrm{CD} 4^{+}$-mediated stimulated $\mathrm{CD}^{+} \mathrm{T}$ lymphocytes, able to lyse primarily macrophages infected with BHV-1 (110). This is a sort of selective removal of viral antigenassociated antigen-presenting cells (APCs). In acute viral infection BHV-l can induce apopto- sis simply through attachment of the viral particles to target cells (111). Therefore, CTLs serve as a major immune mechanism against BHV-1 infection as well as selective eliminators of infected cells (110).

\section{BHV-1 and Cytokines}

Cytokines are physiologically important immunomodulators that are produced by many different cell types and that exert broad pleiotropic effects. Many of these effects are important in host defense mechanisms against viral infections. Even without complete bovine gene maps, those developed thus far have been used to identify genetic markers that are associated with increased zootechnics production or enhanced disease resistance and that can be manipulated in selective breeding programs. This type of study makes it possible to correlate, for instance, a specific interferon (IFN) genotype and the severity of clinical development following herpesvirus infection (112).

IFN- $\gamma$ plays an important role in the generation of non-MHC-restricted cytotoxic responses of cattle to BHV-1, which represents the most apparent cellular-mediated immune response during BHV-1 infection (105). More recent studies on the role of IFN- $\gamma$ in host immunity to other herpesviruses revisited the issue of IFN- $\gamma^{\prime}$ 's essential participation in the control of infection. IFN- $\gamma$ seems to be required to contain the initial infection, but the functions mediated by $\mathrm{T}$ cells appear to proceed effectively even in the absence of IFN- $\gamma(113)$. The conclusion is that IFN- $\gamma$, by enhancing $\mathrm{T}$ cell-mediated clearance mechanisms, might be a critical mediator of immunity to herpesvirus. IFN- $\gamma$ should be considered in terms of the major and compensatory mechanisms available to the body to effect immunity to viral infection (114). Some herpesviruses (e.g., HHV-8) were recently shown to express a protein hampering IFN- $\gamma$ actions. Such a discovery will shed new light on molecular mechanisms that intimately regulate virus-host interactions.

$\alpha$ - and $\beta$-IFN inhibit the induction of TK enzyme activity in vitro (115). Interleukin-2 (IL-2) was originally considered a $T$ cell growth factor; it is a glycoprotein secreted by a subset of $T$ cells and large granular lymphocytes after stimulation. IL-2 supports growth and differentiation of antigen-activated $\mathrm{T}$ lymphocytes, and play a role in a cascade of immunological events: it is known to affect the growth of B cells, NK and lymphokine-activated killer (LAK) cells, and to 
influence the oxidative burst by mononuclear phagocytes (116). IL-2, when administered in vivo to BHV-1-infected calves, enhances antiviral immunity through both PBMC-mediated lysis of BHV-1-infected cells and serum neutralization antibodies to BHV-1, without causing side effects. Therefore, IL-2 may be an effective adjuvant to immunize against infectious diseases $(117,118)$. It has also been shown that in vivo administration of bovine IL- $1 \beta$, a macrophage/ monocyte-derived cytokine, induces immunoenhancing activity against BHV-1, therefore IL- $1 \beta$ may, too, be an effective adjuvant to BHV-1 immunization (119-121).

\section{BHV-1 as a Viral Vector}

Methods of introducing foreign DNA into cells have led to many recent advances in molecular genetics. Transfer of therapeutic or prophylactic genes to the body to treat both inherited and acquired diseases are among the most revolutionary technologies currently developed. Adenovirus, baculovirus, papovavirus, and poxvirus have been used as vectors for transient overexpression of recombinant proteins and for vaccine development. In addition, several viral vectors have been considered potential tools for gene therapy. Indeed, herpesviruses are attractive vector candidates for three major reasons: they can efficiently infect postmitotic nondividing neurons; they can establish a latent infection in some nondividing neuronal cells; and their genome, which is quite large, is relatively easy to manipulate $(122,123)$. Further experiments are required for defining parameters that control viral and cellular gene expression in neurons, to accomplish consistent, regulated, and predictable gene expression.

HSV-based vectors can deliver foreign genes into postmitotic cells, leading to the development of gene therapy approaches to treat neurological diseases and cancer. BHV-1 has several properties that make it an ideal candidate to serve as a vector for heterologous genes. First, BHV-1 infects only cattle, thus entailing few public health considerations. Second, live, attenuated vaccine strains of BHV-1 already exist and have been safely used in cattle for many years. Third, alphaherpesviruses have been used to express genes from other viruses (124). Thus, engineered BHV-1 can prove useful as a vector for the expression of foreign proteins with immunogenic purposes, once two minimal requirements are fulfilled. First, viral vector should have a nonessential site into which foreign genes can be inserted without hampering viral replication; second, its genome must be large enough to accommodate foreign DNA, allowing it to be packed up efficiently (in HSV and other herpesviruses, up to $20 \mathrm{~kb}$ can be accommodated) $(54,114,124)$.

Recombinant IBRV vectors expressing footand-mouth disease virus capsid VPI epitopes have been described (125). Other IBRVs carry genes coding for "late" glycoprotein and "early" enzymes of porcine pseudorabies virus $(126,127)$. Bacterial genes have also been successfully expressed in BHV-1, e.g., Escherichia coli lacZ gene (54).

BHV-l vector has proven its effectiveness in delivering foreign products (e.g., antigens) to mucosal surfaces of the respiratory tract (54). Moreover, BHV-1, being a neurotropic virus like HSV-1, is also considered a suitable candidate for neuronal gene delivery.

\section{Prophylaxis: Vaccines and Eradication}

IBR-free countries have achieved this status by applying diagnostic and slaughtering programs for serologically positive animals. Such a method works well where an infection shows a low prevalence (128). In countries with high infection rates, however, diagnosis-and-eradication procedures would cause large financial losses. Here the best way to eradicate infection is based on combined vaccination-eradication programs. Indeed, vaccination is the most cost-effective measure to prevent and limit infections. The primary aim in using BHV-1 vaccines is to reduce signs of disease and thereby the economic impact of BHV-1 infections. Currently available vaccines do not prevent the establishment of BHV-1 in a latent state. It is not known whether passive immunity can prevent viral excretion and latency after primary infection. However, passive immunity acquired from colostrum was proved to protect newborn calves against the fatal multisystemic diseases caused by BHV-1 infection (129). Maternal antibodies do not prevent initial viral replication, allowing onset of latency. Once maternal antibodies get lost, animals likely become seronegative carriers of latent virus, since seroconversion or reactivation can take place. IBR control programs should therefore take into account the existence of latently infected seronegative animals (130). 
BHV-1 is a suitable example showing the evolution of possible conventional and modern vaccine strategies over many years. Classic vaccines belong to two different classes: live attenuated and inactivated agent vaccines. Conventional killed or modified live vaccines were the only vaccines available until a decade ago. They did not reduce the prevalence of IBR infection. Recent advances in genetically engineered techniques as well as better understanding of the virulence factors and protective components of BHV-1 have led to the development of a remarkable new generation of vaccines: a variety of subunit, synthetic, peptide, DNA, and live-agent recombinant vaccines are now available (131).

\section{Live and Killed Conventional Vaccines}

The first isolation of BHV-1 was published in 1956 (132) and, in that same year, the first attenuated live vaccine was reported (133). Since that time, a wide variety of live and killed vaccines has been developed. Virus strains used to prepare live vaccines are usually attenuated by multiple passages in cell culture (134). A widely used live BHV-1 vaccine contains RLB 106 strain, a temperature-sensitive virus obtained by treatment with nitrous acid and selection (135). Live vaccines have been developed for intramuscolar or intranasal application, and usually induce a strong and long-lasting immunity. However, a major constraint limiting the use of such vaccines is the lack of simple methods to differentiate vaccine strains from field strains. Restriction analysis, albeit effective, is not easy and cannot be quickly carried out (136). Another disadvantage is the lack of well-characterized mutations/ deletions in vaccine virus; this may lead to genomic recombinations with wild-type strains, thus allowing a harmful reversion to virulence of live vaccines (137).

The virus strains used in killed vaccines, once grown in cell culture, are inactivated by chemical or physical treatments, for example, alkylating agents or heat. Adjuvants must be added to enhance protective immune responses evoked by the inactivated virus alone. The choice of adjuvant, the inactivating agent, and the amount of antigen are critical factors for the quality of an inactivated vaccine (138). The subunit vaccine is a special type of killed vaccine that does not contain the whole virion but selected components of it, for instance, envelope glycoproteins (139).

Live vaccines are more effective than killed ones, because they better simulate a natural infection. Killed vaccines, on the other hand, are usually safer because of their inability to replicate in the host. Live and killed conventional BHV-1 vaccines have been compared: the efficacy of live vaccines was found to be superior to that of killed vaccines (140).

Conventional vaccines usually prevent severe clinical signs from developing after BHV-1 infection, and thereby diminish economical losses. Most conventional BHV-1 vaccines only restrict the amount of virus shed after infection in herds. A disadvantage of conventional vaccines is their interference with routine sero-epidemiological surveys, which make eradication programs hard to be applied. Moreover, some conventional live BHV-1 vaccines have given rise to several unwanted side effects, such as mild disease or even death after vaccination (141), transmission after intranasal vaccination (142), reactivation of latent vaccine strain (143), enhancement of keratoconjunctivitis (144) and abortion (145), and ovarian lesions (146,147). In addition, BHV-1 vaccines have been found on occasion to be contaminated (148). Killed vaccines may induce local tissue reactions or abscess and hypersensitivity reactions (131).

\section{Engineered Subunit Vaccines}

In order to develop effective strategies of subunit immunization, it is important to recognize the role of major glycoproteins both in inducing antibody and in stimulating cell-mediated response. Since BHV-1, like other viruses, enters cells by interacting with host cell receptors, a convenient point of intervention is to counteract interactions between host cells and viral surface glycoproteins. BHV-l glycoproteins gI, gIII, and gIV are involved in attachment to host cells and in virus entry. Animals immunized against gI, gIII, and gIV produce neutralizing antibodies able to block virus infectivity in vitro and even significantly limit virus replication in vivo (149). Major BHV-l glycoproteins are known immunodominant antigens $(150,151)$ : bovine immune responses are addressed to gI (homologous to HSV-1 gB), gIII (homologous to HSV-1 gC), and gIV (homologous to HSV-1 gD) (152-155).

A second target for vaccines is proteins eliciting cytotoxic responses. These are targeted by cytotoxic $\mathrm{T}$ cells, which lyse virus-infected cells before the virus carries out its replicative cycle, thus reducing the overall virus load and clinical disease. The IE proteins of herpesviruses are pri- 
mary targets of CTLs (156). Efficient genetically engineered vaccines should induce the production of antibodies or stimulate cytotoxic $\mathrm{T}$ cells directed against early surface glycoproteins expressed on host cells long before infectious viral particles are released; this should be more effective than mere killing of intact virus or virusbudding infected cells. gI and gIV glycoproteins, early expressed after cell infection and long before BHV-1 is released from virus-infected cells, were shown fit to immunize cattle (61).

Subunit vaccines are safer than live ones, being made of recombinant viral antigens. However, all such vaccines need adjuvants to evoke a stronger and effective immune response. The search for better adjuvants has brought about an evaluation of the role of cytokines in such vaccines: the immune response to subunit vaccines is enhanced when IL- 2 or IL- $1 \beta$ are added to common adjuvants $(118,120)$.

Major viral proteins involved in infection and replication have been produced in various expression systems (157-159). Challenge of animals vaccinated with recombinant gIV produced in different expression systems $(E$. coli, vaccinia virus, adenovirus, baculovirus, and mammalian cells) showed that all proteins were immunogenic, but not all raised neutralizing antibodies in vaccinated hosts, thus blocking onset of clinical symptoms and virus shedding. For example, $E$. coli produced recombinant gIV was immunogenic, but homologous proteins from mammalian and insect cells showed a better capacity for inducing neutralizing antibody and reducing viral shedding (160-162).

In some cases, immunogenicity of single antigens or subunits can be improved by rebuilding a whole particle through addition of phospholipids, cholesterol, or steroid adjuvants such as Quil A. BHV-1 antigens induced strong immunity when administered as liposomes or through immunostimulating complexes (ISCOMS) technology (163). Virus-like particles expressing varicella zoster virus (VZV) antigens have also been shown to induce protective immunity in mice (164). Timing and controlled release of antigens may also help to establish an effective immunity in the host $(163,165,166)$.

\section{Modified Live Vaccines}

Recent advances in our understanding of specific virulence genes of $\mathrm{BHV}-1$ and other herpesviruses have made possible the specific deletion of genes to accomplish genetic attenuation of viral strains (167). Some structural genes (e.g., gIII, $g E$ ) and some genes involved in nucleic acid metabolism (e.g., $t k$ gene) can be deleted without significantly affecting viral replication in vitro. This opens the way to the development of BHV-1 strains carrying specific deletions (168-172).

The deletion of $t k$, a gene involved in nucleic acid metabolism, or the ablation of sequences coding for glycoprotein genes (e.g., $g C$ or $g E$ ) caused a dramatic change in virulence of BHV-1 in vivo (Fig. 4). This approach also allowed development of diagnostic in vitro tests to differentiate vaccinated animals from seronegative latent carriers $(154,155,173)$. Through this strategy marker vaccines have been developed, i.e., vaccines based on single or multiple deletion of inessential genes, allowing discrimination between vaccinated and naturally infected animals through their antibody responses. In other words, vaccinated animals lack antibodies against a strongly immunogenic but unprotective viral protein that evokes immune responses in hosts following natural infection with field viral strains. Such marker protein is not expressed in vaccine viruses, allowing a suitable immunoscreening procedure to be set up and carried out. Hence, a marker vaccine, used in conjunction with suitable serological tests, enables use of diagnosis-and-eradication strategies in highly infected herds, because vaccination cannot be misled with natural infection, significantly reducing viral transmission rate. Additional advantages of marker vaccines are (l) the seroepidemiology of infections can be studied in a vaccinated population; (2) the use of vaccines no longer interferes with serological diagnosis on a herd or individual level; and (3) the efficacy of vaccines can be well evaluated under field conditions $(20,56,174)$. Modified-live BHV-1 virus mutants, irreversibly attenuated by deletions in $t k$ gene and marker genes, e.g., $g E$, provide safe, efficacious, and rationally designed vaccines. In conjunction with sensitive and specific differential ELISA diagnostic tests, these latter vaccines enable veterinarians to distinguish vaccinated animals from those infected with field strains (175).

A $t k$-deficient, $g C$-deleted, mutant BHV-1 protected cattle against IBR and reduced viral shedding upon challenge (176). Calves inoculated with genetically engineered $g G$ - or $g E$-deleted mutant strains were better protected against challenge than those given a $g I$ or $g I / g E$ double-deleted mutant virus (168). Although $g E$-negative BHV-1 can establish latency in trigeminal ganglia (103), no adverse effects were 
BHV-1

wild-type strain

infection
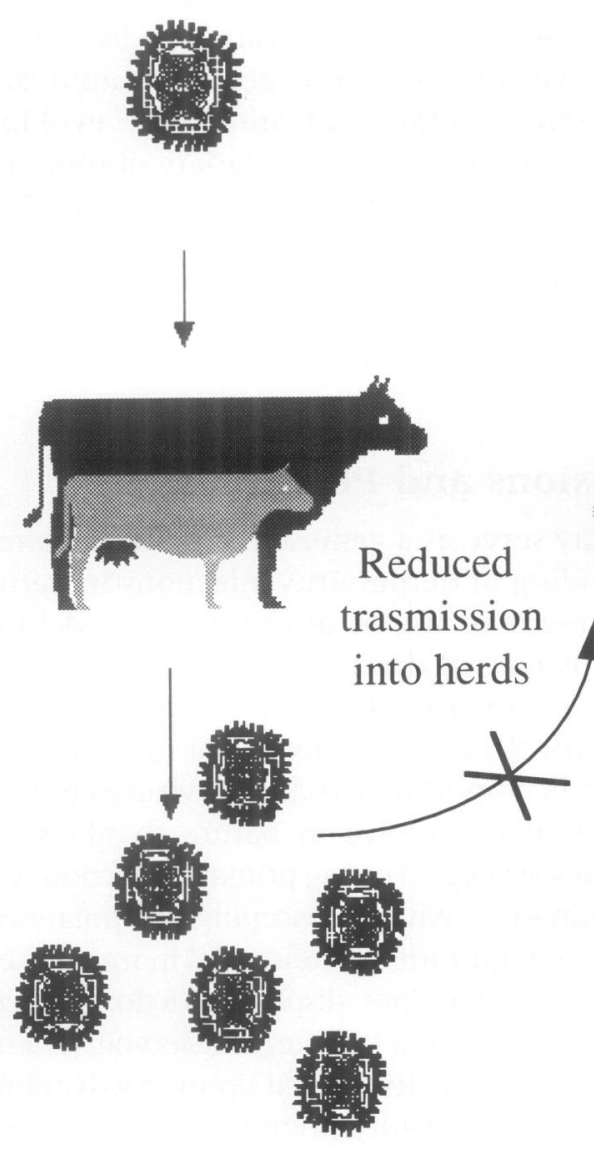

Symptoms

BHV-1 related diseases
Discrimination between vaccinated
and naturally infected animals

Asymptomatic carriers tk- \& $g E-$

(live attenuated and negative marker)

BHV-1 vaccine
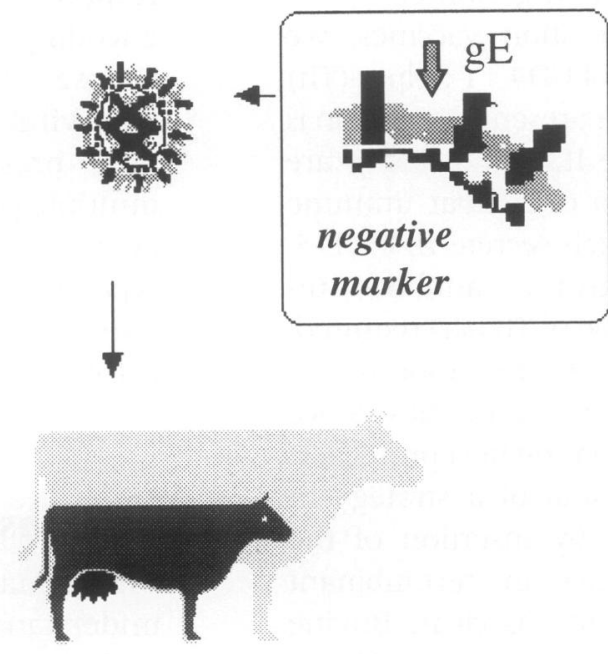

Reduced or abolished

symptoms and viral shedding

Fig. 4. Live attenuated BHV-1 vaccines carrying negative immunological markers. Their advantages in prophylaxis and eradication of BHV-1 infection are shown. observed in calves $(177,178)$. Mutant viruses carrying different deletions in genes encoding nonessential glycoproteins $(g C, g E, g I$, and $g G)$ were compared after induction of cell-mediated immune response. The gC-negative mutant showed the best response (179). An alternative modified BHV-1 marker vaccine was obtained by introducing bacterial $\beta$-galactosidase-coding gene (lac $Z$ ) within the $t k$ sequence. The resultant recombinant strain contains a chimeric reporter/ marker gene as well as the $t k$ gene deletion. This attenuated virus, expressing $\beta$-gal marker, was easily distinguishable from wild-type strains by phenotypic/histochemical assay (180).

It is possible to produce polyvalent vaccines by engineering herpesviruses to express foreign antigens at the same time. Large genome of BHV-1 and other herpesviruses may allow the use of multiple insertion sites. It would provide the opportunity to introduce a number of genes 
belonging to viruses, bacteria, or parasites. Cytokines, which have a major role in modulating immune response of the host, have been recently inserted in the BHV-1 modified genome.

In developing next-generation vaccines, we need to consider the balance of $\mathrm{CD} 4^{+} \mathrm{T}$ helper (Th) cell subsets induced. Since the present perception is that Thl cells, which secrete IL- 2 and IFN- $\gamma$, are associated with the induction of cellular immune responses, and Th2 cells, which secrete IL-4, IL-5, IL-6, and IL-10, evoke high-titer antibody responses, depending on the type of Th bias required, it is possible to direct the immune response by immunization in the presence of cytokines. Since cytokines are involved in mediating host protection against pathogens, the potential of a strategy in which delivery of cytokines by insertion of the corresponding encoding genes in recombinant BHV-1, administered as vaccine, is clear. Bovine IL-2 and IL-4 expressed in recombinant BHV-1 were secreted as biologically active glycoproteins (181). IL- $1 \beta$ has been shown to be an immunological adjuvant that influences a broad spectrum of biological activities within the hematopoietic and immunological systems (182). For instance, administration of IL- $1 \beta$ and modified live BHV-1 vaccine enhanced both the humoral and cellular immune response against BHV-1 $(119,120)$. Therefore recombinant BHV-1 has been chosen to set a system of in vivo cytokine delivery (183). The creation of recombinant BHV-1 expressing biologically active cytokines overcomes the two drawbacks of co-administration of cytokines as adjuvants: the toxic side effects often resulting from the administration of large doses required to develop an adjuvant effect and the difficulty of administering the cytokine adjuvant at the localized site of infection.

\section{Genetic Immunization (DNA Vaccines)}

One of the major problems with many vaccines is the duration of immunity. Moreover, many vaccines are not effective when administered in the presence of maternal antibodies. Genetic immunization can overcome these problems, because plasmids encoding specific genes can work and express in vivo corresponding proteins when introduced into animals and humans. Nucleic acid vaccination appears to be quite efficacious, and plasmids are easily prepared, purified, and delivered in hosts. Moreover, DNA vaccines are safer than viral strains and antigens mixtures, and inexpensive compared to other vaccines. The first experiments were promising: five injections with a plasmid encoding BHV-1 gD elicited protective immunity in calves (184).

While subunit vaccines primarily elicit Th2 response, DNA immunization with plasmids encoding single glycoproteins stimulate Thl responses (184). Both subunit vaccines, live modified viral vectors as well as genetic immunization, present a major advantage in evoking multiple protection for a wide variety of proteins belonging to a single or different pathogen. The type and the duration of immune response may also be specifically addressed by administering cytokine-coding genes.

\section{Conclusions and Perspectives}

BHV-1 may serve as a general model for a better understanding of herpesvirus infections in natural hosts and may also be of value as a model for herpesvirus-caused diseases, which are also important for humans. The increasing literature dealing with BHV-1 provides proof of economic and scientific importance of herpesviruses today.

Herpesviruses survive in nature thanks to a double-track strategy. During primary infection, viral dissemination within susceptible populations raises a strong immune response and in most cases the population does not display infection-associated diseases creating a long-term reservoir (latent virus) that becomes meaningful upon reactivation. Then, apparently healthy animals are able to reexcrete and transmit the virus to nonimmune and immune hosts. Herpesviruses have an efficient machinery for making this strategy effective. A set of essential genes is able to produce a high titer of infectious particles during primary infection and reactivation. A second set of nonessential and conditional-essential genes are required to establish latency, reactivation, virulence, and modulation of the host's immune response. In recent years, wide breakthroughs have led to the discovery of the BHV-1 life cycle; however, its efficiency in infecting and replicating depends not only on viral but also on the host's factors (9).

Efficacy and safety are the main criteria for assessing the quality of vaccines (185). The efficacy of vaccines is primarily assessed by a vaccination-challenge experiment in the target host (bovine). Subsequently, the vaccine's ability to reduce virus transmission is evaluated and evaluation of the vaccine's effectiveness is finalized in a field trial. Safety of BHV-1 vaccines is assessed by a series of experiments, usually with a 10 -fold dose of vaccine in field trials (133). The 
effect of spreading capacity in cattle population, infection of non-target animals, and reversion to virulence are also tested (186).

The precise mechanisms underlying induction and maintenance of protective immunity after vaccination are far from being clearly understood. Protective immunity consists of immunity against fever, development of nasal lesions, other signs of disease, viral replication, viral shedding, or against infection. These criteria of immunity are based on different immunological processes. The elucidation of immunological mechanisms underlying the protective immunity should lead to the development of more effective BHV-1 vaccines. A better understanding of the pathogenesis of BHV-1 will also certainly contribute to a more rapid development of novel vaccines. Since only the first generation of marker vaccines has been developed recently, there is room for improving the efficacy of vaccines.

Although no completely efficacious vaccines are available against BHV-1 and other herpesviruses, more insight into the mechanisms of immunity should be stimulated. Advances in identification of different lymphocyte subsets in cattle, more insight into the complex interaction between the different immune cells with each other and the target, beginning elucidation of the roles of cytokines, and increasing emphasis on the development of more efficient adjuvants and delivery systems promise a better understanding of how to stimulate a protective immune response in vaccinated animals (187).

\section{References}

1. Metzler AE, Matile H, Gassmann U, Engels M, Wyler E. (1985) European isolates of bovine herpesvirus 1: a comparison of restriction endonuclease sites, polypeptides and reactivity with monoclonal antibodies. Arch. Virol. 85: 57-69.

2. Misra V, Babiuk LA, Darcel CQ. (1983) Analysis of bovine herpesvirus type 1 isolates by restriction endonuclease fingerprinting. Arch. Virol. 76: 341-354.

3. Engels M, Steck F, Wyler R. (1981) Comparison of the genomes of infectious bovine rhinotracheitis and infectious pustolar vulvovaginitis virus strains by restriction endonuclease analysis. Arch. Virol. 67: 169-174.

4. Whetstone CA, Seal BS, Miller JM. (1993) Variability occurs in the inverted repeat region of genomic DNA from bovine herpesvirus 1 respiratory, genital and bovine herpesvirus 5 encephalitic isolates. Vet. Microbiol. 38: 181-189.
5. Seal BS, Whetstone CA. (1994) Immediate-early gene expression and gene mapping comparisons among isolates of bovine herpesvirus 1 and 5. Vet. Microbiol. 38: 369-384.

6. Bratanich AC, Sardi SI, Smitsaart EN, Schudel AA. (1991) Comparative studies of BHV-1 variants by in vivo-in vitro tests. J. Vet. Med. B 38: 41-48.

7. Mayfield JE, Good PJ, van Oort HJ, Campbell AR, Reed DE. (1983) Cloning and cleavage site mapping of DNA from bovine herpesvirus 1 (cooper strain). J. Virol. 47: 259-264.

8. Castrucci G, Frigeri F, Ranucci S, et al. (1984) Comparative studies of strains of infectious bovine rhinotracheitis virus isolated from latently infected calves. Comp. Immunol. Microbiol. Infect. Dis. 7: 1-10.

9. Engels M, Ackermann M. (1996) Pathogenesis of ruminant herpesvirus infections. Vet. Microbiol. 53: 3-15.

10. Yates DWG. (1982) A review of infectious bovine rhinotracheitis, shipping fever pneumonia and viral-bacterial synergism in respiratory disease of cattle. Can. J. Comp. Med. 46: 225-263.

11. van Oirschot JT. (1995) Bovine herpesvirus 1 in semen of bulls and the risk of transmission: a brief review. Vet. Q. 17: 29-33.

12. Misra PK, Mishra A. (1987) Infectious bovine rhinotracheitis infection and infertility in cows, heifers and bulls. Indian J. Anim. Sci. 57: 267-271.

13. Parsonson IM, Snowdon WA. (1975) The effect of natural and artificial breeding using bulls infected with, or semen contaminated with, infectious bovine rhinotracheitis virus. Aust. Vet. J. 51: 365-369.

14. Bielanski A, Loewen KG, Hare WCD. (1988) Inactivation of bovine herpesvirus-1 (BHV-1) from in vitro infected bovine semen. Theriogenology 30: 649-657.

15. Wyler R, Engels M, Schwyzer M. (1989) Infectious bovine rhinotracheitis/vulvovaginitis (BHV-1). In: Wittman G (ed). Herpesvirus Diseases of Cattle, Horses and Pigs. Kluwer Academic Publishers, Boston, pp. 1-72.

16. Thiry E, Saliki J, Pastoret P-P, Lambert A-F, Ligot J. (1984) Failure to demonstrate infectious bovine rhinotracheitis virus reactivation in parturient cows. Vet. Rec. 8: 248-249.

17. Van Wuijckhuise L, Bosch J, Franken P, Frankena K, Elbers ARW. (1998) Epidemiological characteristics of bovine herpesvirus 1 infections determined by bulk milk testing of all Dutch dairy herds. Vet. Rec. 142: 181-184.

18. Pastoret P-P, Thiry E. (1985) Diagnosis and prophylaxis of infectious bovine rhinotracheitis: the role of virus latency. Comp. Immun. Microbiol. Infect. Dis. 8: 35-42.

19. Thiry E, Saliki J, Bublot M, Pastoret P-P. (1987) Reactivation of infectious bovine rhinotracheitis 
virus by transport. Comp. Immun. Microbiol. Infect. Dis. 10: 59-63.

20. Geng Y, Kashanchi F, Wood C. (1992) Activation of bovine immunodeficiency-like virus expression by bovine herpesvirus type 1. Virology 187: 832-836.

21. Arthington JD, Corah LR, Blecha F. (1996) The effect of molybdenum-induced copper deficiency on acute-phase protein concentrations, superoxide dismutase activity leukocyte numbers, and lymphocyte proliferation in beef heifers inoculated with bovine herpesvirus-1. J. Anim. Sci. 74: 211-217.

22. Hage JJ, Schukken YH, Barkema HW, Benedictus G, Rijsewjk FAM, Wentink GH. (1996) Population dynamics of bovine herpesvirus 1 infection in a dairy herd. Vet. Microbiol. 53: 169-180.

23. Tanyi J, Varga J. (1992) Guidelines for the eradication of bovine rhinotracheitis in Hungary. Acta Vet. Hung. 40: 165-169.

24. Homan EJ, Easterday BC. (1980) Isolation of bovine herpesvirus-1 from trigeminal ganglia of clinically normal cattle. Am. J. Vet. Res. 41: 12121213.

25. Ackerman M, Peterhans E, Wyler R. (1982) DNA of bovine herpes virus type 1 in the trigeminal ganglia of latently infected calves. Am. J. Vet. Res. 43: $36-40$.

26. Drew TW, Hewitt-Taylor C, Watson L, Edwards S. (1987) Effect of storage conditions and culture technique on the isolation of infectious bovine rhinotracheitis virus from bovine semen. Vet. Rec. 121: $547-548$.

27. Loewen KG, Darcel C. (1985) A comparison of two methods for the isolation of bovine herpesvirus 1 (BHV-1) from extended bovine semen. Theriogenology 23: 935-943.

28. Brunner D, Engels $M$, Schwyzer $M$, Wyler $R$. (1988) A comparison of three techniques for detecting bovine herpesvirus type 1 (BHV-1) in naturally and experimentally contaminated semen. Zuchthung 23: 1-9

29. Wentink GH, Rutten VPMG, van Exel ACA, De Jong WAC, Vleugel H, Hensen EJ. (1990) Failure of an in vitro lymphoproliferative assay specific for bovine herpesvirus type 1 to detect immunized or latently infected animals. Vet. Q. 12: 175-182.

30. Florent G, De Marneffe C. (1986) Enzyme linked immunosorbent assay used to monitor serum antibodies to bovine respiratory disease viruses. Vet. Microbiol. 11: 307-317.

31. Edwards S, Woods SB, Westcott DG, Emmerson M, Jones PC, Phillips AJ. (1986) An evaluation of five serological tests for the detection of antibody to bovine herpesvirus 1 in vaccinated and experimentally infected cattle. Res. Vet. Sci. 41: 378382.

32. Kramps JA, Quak S, Weer Dmeester K, van Oirschot JT. (1993) Comparative study on sixteen enzyme-linked immunosorbent assays for the detection of antibodies to bovine herpesvirus 1 in cattle. Vet. Microbiol. 35: 11-21.

33. Derget D, Cho HJ, Kozub GC. (1993) A comparative evaluation of two sensitive serum neutralizing tests for bovine herpes-1 antibodies. Can. J. Vet. Res. 57: 56-59.

34. Abdelmagid OY, Mansour MM, Minocha HC, van Drunen Littel-van den Hurk S. (1998) Evaluation of baculovirus-expressed bovine herpesvirus-1 (BHV-1) glycoproteins for detection and analysis of BHV-1-specific antibody responses. Vet. Microbiol. 61: 249-259.

35. Kramps JA, Perrin B, Edwards S, van Oirschot JT. (1996) A European inter-laboratory trial to evaluate the reliability of serological diagnosis of bovine herpesvirus 1 infections. Vet. Microbiol. 53: 153-161.

36. van Donkersgoed J, Babiuk L. (1991) Diagnosing and managing the respiratory form of infectious bovine rhinotracheitis. Vet. Med. 1: 86-94.

37. Andino RH, Torres HN, Polacino PS, Schudel A, Palma EL. (1987) Detection of bovine herpesvirus-1 nucleic acid sequences, using a dot-blot hybridization procedure. Am. J. Vet. Res. 48: 984987.

38. Vilcek S, Deliova I, Forgac O, et al. (1993) Detection of bovine herpesvirus 1 with various types of DNA probes. Acta Vet. Hung. 41: 179190.

39. van Engelenburg FAC, van Schie FW, Rijsewijk FAM, van Oirschot JT. (1995) Excretion of bovine herpesvirus 1 in semen is detected much longer by PCR than by virus isolation. J. Clin. Microbiol. 33: 308-312.

40. Kibenge FSB, Harris LM, McKenna PK, Wadowska D, Yason CV. (1994) Amplification of strains of bovine herpesvirus 1 by use of polymerase chain reaction with primers in the thymidine kinase region. Am. J. Vet. Res. 55: 12061212.

41. Yason CV, Harris LM, McKenna PK, Wadowska D, Kibenge FSB. (1995) Establishment of conditions for the detection of bovine herpesvirus- 1 by polymerase chain reaction using primers in the thymidine kinase region. Can. J. Vet. Res. 59: 94101.

42. Vilcek S, Nettleton PF, Herring JA, Herring AJ. (1994) Rapid detection of bovine herpesvirus 1 (BHV 1) using the polymerase chain reaction. Vet. Microbiol. 42: 53-64.

43. van Engelenburg FAC, Maes RK, van Oirschot JT, Rijsewijk FAM. (1993) Development of a rapid and sensitive polymerase chain reaction assay for detection of bovine herpesvirus type 1 in bovine semen. J. Clin. Microbiol. 31: 31293135.

44. Wiedmann $M$, Brandon R, Wagner P, Dubovi EJ, Batt CA. (1993) Detection of bovine herpesvi- 
rus-1 in bovine semen by a nested PCR assay. J. Virol. Methods 44: 129-140.

45. Masri SA, Olson W, Nguyen PT, Prins S, Deregt D. (1996) Rapid detection of bovine herpesvirus 1 in the semen of infected bulls by a nested polymerase chain reaction assay. Can. J. Vet. Res. 60: 100-107.

46. Asbaugh SE, Thompson KE, Belknap EB, Schultheiss PC, Chowdhury S, Collins JK. (1997) Specific detection of shedding and latency of bovine herpesvirus 1 and 5 using a nested polymerase chain reaction. J. Vet. Diagn. Invest. 9: 387-394.

47. Lyaku JRS, Vilcek S, Nettleton PF, Marsden HS. (1996) The distinction of serologically related ruminant alphaherpesviruses by the polymerase chain reaction (PCR) and restriction endonuclease analysis. Vet. Microbiol. 48: 135-142.

48. Rusvai M, Fodor L. (1998) Occurrence of some viruses and bacteria involved in respiratory diseases of ruminants in Hungary. Acta Vet. Hung. 46: 405-414.

49. Schwyzer M, Ackermann M. (1996) Molecular virology of ruminant herpesviruses. Vet. Microbiol. 53: 17-29.

50. Tikoo SK, Fitzpatrick DR, Babiuk LA, Zamb TJ. (1990) Molecular cloning, sequencing, and expression of functional bovine herpesvirus 1 glycoprotein gIV in transfected bovine cells. J. Virol. 64: 5132-5142.

51. Tikoo SK, Zamb TJ, Babiuk LA. (1993) Analysis of bovine herpesvirus 1 glycoprotein gIV truncation and deletions expressed by recombinant vaccinia viruses. J. Virol. 67: 2103-2109.

52. Chase CCL, Lohff C, Letchworth GJ. (1993) Resistance and susceptibility of bovine cells expressing herpesviral glycoprotein D homologous to herpesviral infections. Virology 194: 365-369.

53. Baranowski E, Keil G, Lyaku J, et al. (1996) Structural and functional analysis of bovine herpesvirus 1 minor glycoproteins. Vet. Microbiol. 53: 91-101.

54. Liang X, Babiuk LA, Zamb TJ. (1992) An in vivo study of a glycoprotein gIII-negative bovine herpesvirus 1 (BHV-1) mutant expressing $\beta$-galactosidase: evaluation of the role of gIII in virus infectivity and its use as a vector for mucosal immunization. Virology 189: 629-639.

55. Geraghty RJ, Krummenacher C, Cohen GH, Eisenberg RJ, Spear PG. (1998) Entry of alpha herpesviruses mediated by poliovirus receptorrelated protein 1 and poliovirus receptor. Science 280: $1618-1620$.

56. Montgomery RI, Warner MW, Lum BJ, Spear PG. (1996) Herpes simplex virus-1 entry into cells mediated by a novel member of the TNF/ NGF receptor family. Cell 87: 427-436.

57. Li Y, van Drunen Littel-van den Hurk S, Babiuk LA, Liang X. (1995) Characterization of cellbinding properties of bovine herpesvirus 1 glycoproteins B, C and D: identification of a dual cell-binding function of gB. J. Virol. 68: 47584768.

58. Varthakavi V, Minocha HC. (1996) Identification of a $56 \mathrm{kDa}$ putative bovine herpesvirus 1 cellular receptor by anti-idiotype antibodies. J. Gen. Virol. 77: 1875-1882.

59. Liang X, Pyne C, Li Y, Babiuk LA, Kowalski J. (1995) Delineation of the essential function of bovine herpesvirus $1 \mathrm{gD}$ : an indication for the modulatory role of $\mathrm{gD}$ in virus entry. Virology 207: 429-441.

60. Spear PG. (1993) Entry of alphaherpesviruses into cells. Semin. Virol. 4: 167-180.

61. Ludwig GV, Letchworth G. (1987) Temporal control of bovine herpesvirus 1 glycoproteins synthesis. J. Virol. 61: 3292-3294.

62. Misra V, Bumenthal RM, Babiuk LA. (1981) Proteins specified by bovine herpesvirus 1 (infectious rhinotracheitis virus). J. Virol. 40: 367-378.

63. Fitzpatrick DR, Babiuk LA, Zamb TJ. (1989) Nucleotide sequence of bovine herpesvirus type 1 glycoprotein gIII, a structural model for gIII as a new member of the immunoglobulin superfamily, and implications for the homologous glycoproteins of other herpesviruses. Virology 173: 4657.

64. Liang X, Babiuk L, Zamb T. (1991) Pseudorabies virus gIII and bovine herpesvirus I gIII share complementary functions. J. Virol. 65: 5553-5557.

65. Liang X, Tang M, Zamb TJ, Babiuk LA, Kowalski J, Tykocinski ML. (1993) Expression of glycoprotein gIII-human decay-accelerating factor chimera on the bovine herpesvirus 1 virion via a glycosyl phosphatidylinositol-based membrane anchor. J. Virol. 67: 4896-4904.

66. Liang X, Babiuk LA, Zamb TJ. (1993) Mapping of heparin-binding structures on bovine herpesvirus 1 and pseudorabies virus gIII glycoproteins. Virology 194: 233-243.

67. Roizman B, Desroisiers R, Fleckenstein B. (1992) The family Herpesviridae: an update. Arch. Virol. 123: 425-449.

68. Whitbeck JC, Bello LJ, Lawrence WC. (1988) Comparison of the bovine herpesvirus 1 gI gene and the herpes simplex virus type $1 \mathrm{gB}$ gene. J. Virol. 62: 3319-3327.

69. Misra V, Blewett EL. (1991) Construction of herpes symplex viruses that are pseudoploid for the glycoprotein B gene: a strategy for studying the function of an essential herpesvirus gene. J. Gen. Virol. 72: 385-392.

70. Misra V, Nelson R, Smith M. (1988) Sequence of a bovine herpesvirus type- 1 glycoprotein gene that is homologous to the herpes simplex gene for glycoprotein B. Virology 166: 542-549.

71. Rauh I, Weiland F, Fehler F, Keil G, Mettenletter TC. (1991) Pseudorabies virus mutants lacking the essential glycoprotein gII can be complemented by glycoprotein gI of bovine herpesvirus 1. J. Virol. 65: 621-631. 
72. Kopp A, Mettenleiter TC. (1992) Stable rescue of a glycoprotein gII deletion mutant of pseudorabies virus by glycoprotein gI of bovine herpesvirus 1. J. Virol. 66: 2754-2762.

73. Fitzpatrick DR, Redmond MJ, Attah-Poku SK, van Drunen Littel-van den Hurk S, Babiuk LA, Zamb TJ. (1990) Mapping of 10 epitopes on bovine herpesvirus type 1 glycoproteins gI and $\mathrm{g}$ III. Virology 176: 145-157.

74. Vlcek C, Benes V, Lu Z, et al. (1995) Nucleotide sequence analysis of a $30-\mathrm{kb}$ region of the bovine herpesvirus 1 genome which exhibits a colinear gene arrangement with the UL21 to UL4 genes of herpes simplex virus. Virology 210: 100-108.

75. Wirth UV, Gunkel K, Engels M, Schwyzer M. (1989) Spatial and temporal distribution of bovine herpesvirus-1 transcripts. J. Virol. 63: 48824889.

76. Wirth UV, Gunkel K, Engels M, Schwyzer M. (1989) Spatial and temporal distribution of bovine herpesvirus 1 transcripts. J. Virol. 63: 48824889.

77. Seal BS, Whetstone CA, Zamb TJ, Bello LJ, Lawrence WC. (1992) Relationship of bovine herpesvirus 1 immediate-early, early and late gene expression to host cellular gene transcription. Virology 188: 152-159.

78. Fraefel C, Zeng J, Choffat $Y$, Engels M, Schwyzer M, Ackermann M. (1994) Identification and zinc dependence of the bovine herpesvirus 1 transactivator protein BICP0. J. Virol. 68: 3154-3162.

79. Singh M, Fraefel C, Bello LJ, Lawrence WC, Schwyzer M. (1996) Identification and characterization of BICP27, an early protein of bovine herpesvirus 1 which may stimulate mRNA 3' processing. J. Gen. Virol. 77: 615-625.

80. Schwyzer M, Vlcek C, Menkse O, Fraefel C, Paces V. (1993) Promoter, spliced leader, and coding sequence for BICP4, the largest of the immediate-early proteins of bovine herpesvirus 1. Virology 197: 349-357.

81. Fraefel C, Ackermann M, Schwyzer M. (1994) Identification of the bovine herpesvirus- 1 circ protein: a myristylated and virion-associated polypeptyde which is not essential for virus replication in cell culture. J. Virol. 68: 8082-8088.

82. Hammerschmidt W, Ludwig H, Buhk H-J. (1988) Specificity of cleavage in replicative-form DNA of bovine herpesvirus 1. J. Virol. 62: 1355-1363.

83. Fraefel C, Wirth UV, Vogt B, Schwyzer M. (1993) Immediate-early transcription over covalently joined genome ends of bovine herpesvirus 1 : the circ gene. J. Virol. 67: 1328-1333.

84. Misra V, Walker S, Hayes S, O'Hare P. (1995) The bovine herpesvirus a gene trans-inducing factor activates transcription by mechanisms different from those of its herpes simplex virus type 1 counterpart V16. J. Virol. 69: 5209-5216.

85. Misra V, Bratanich AC, Carpenter D, O'Hare P. (1994) Protein and DNA elements involved in transactivation of the promoter of the bovine herpesvirus (BHV) l IE-1 transcription unit by the BHV $\alpha$ gene trans-inducing factor. J. Virol. 68: 4898-4909.

86. Huang CC, Herr W. (1996) Differential control of transcription by homologous homeodomain coregulators. Mol. Cell. Biol. 16: 2967-2976.

87. Wirth UV, Vogt B, Schwyzer M. (1991) The three major immediate-early transcripts of bovine herpesvirus 1 arise from two divergent and spliced transcription units. J. Virol. 65: 195-205.

88. van Drunen Littel-van den Hurk S, Garzon $S$, van den Hurk JV, Babiuk LA, Tijssen P. (1995) The role of the major tegument protein VP8 of bovine herpesvirus-1 in infection and immunity. Virology 206: 413-425.

89. Wirth UV, Fraefel C, Vogt B, Vlcek C, Paces V, Schwyzer M. (1992) Immediate-early RNA 2.9 and early RNA 2.6 of bovine herpesvirus 1 are $3^{\prime}$ coterminal and encode a putative zinc finger transactivator protein. J. Virol. 66: 2763-2772.

90. Huemer HP, Larcher C, van Drunen Littel-van den Hurk S, Babiuk L. (1993) Species selective interaction of Alphaherpesvirinae with the "unspecific" immune system of the host. Arch. Virol. 130: 354-364.

91. Jacobs L. (1994) Glycoprotein E of Pseudorabies virus and homologous proteins of other alphaherpesvirinae. Arch. Virol. 137: 209-228.

92. Hariharan MJ, Nataraj C, Srikumaran S. (1993) Down regulation of murine $\mathrm{MHC}$ class I expression by bovine herpesvirus 1. Viral Immunol. 6: 273-284.

93. Kutish G, Mainprize T, Rock D. (1990) Characterization of the latency-related transcriptionally active region of the bovine herpesvirus 1 genome. J. Virol. 64: 5730-5737.

94. Schang LM, Hossain A, Jones C. (1996) The latency-related gene of bovine herpesvirus-1 encodes a product which inhibits cell cycle progression. J. Virol. 70: 3807-3814.

95. Jiang Y, Hossain A, Winkler MT, Holt T, Doster A, Jones C. (1998) A protein encoded by the latency-related gene of bovine herpesvirus $l$ is expressed in trigeminal ganglionic neurons of latently infected cattle and interacts with cyclindependent kinase 2 during productive infection. J. Virol. 72: 8133-8142.

96. Jones C, Delhon G, Bratanich A, Kutish G, Rock D. (1990) Analysis of the transcriptional promoter which regulates the latency-related transcript of bovine herpesvirus 1. J. Virol. 64: $1164-$ 1170.

97. Bratanich AC, Jones CJ. (1992) Localization of cis-acting sequences in the latency-related promoter of bovine herpesvirus 1 which are regulated by memorial cell type factors and immediate-early genes. J. Virol. 66: 6099-6106.

98. Bratanich AC, Hanson ND, Jones CJ. (1992) The latency-related gene of bovine herpesvirus 1 in- 
hibits the activity of immediate-early transcription unit 1. Virology 191: 988-991.

99. Devireddy LR, Jones C. (1998) Alternative splicing of the latency-related transcript of bovine herpesvirus 1 yields RNAs containing unique open reading frames. J. Virol. 72: 7294-7301.

100. Schang LM, Jones C. (1997) Analysis of bovine herpesvirus 1 transcripts during a primary infection of trigeminal ganglia of cattle. J. Virol. 71: 6786-6795.

101. Whetstone CA, Miller IM, Seal BS, Bello LJ, Lawrence WC. (1992) Latency and reactivation of a thymidine kinase-negative bovine herpesvirus 1 deletion mutant. Arch. Virol. 122: 207-214.

102. Rock D, Lokensgard J, Lewis T, Kutish G. (1992) Characterization of dexamethasone-induced reactivation of latent bovine herpesvirus 1. J. Virol. 66: $2484-2490$.

103. van Engelenburg FAC, Kaashoek MJ, van Oirschot JT, Rijsewijk FAM. (1995) A glycoprotein E deletion mutant of bovine herpesvirus 1 infects the same limited number of tissue in calves as wild-type virus, but for a shorter period. J. Gen. Virol. 76: 2387-2392.

104. Bielefeldt O, Babiuk LA, Harland R. (1991) Cytokine synergy with viral cytopathic effects and bacterial products during the pathogenesis of respiratory tract infection. Clin. Immunol. Immunopathol. 60: 153-170.

105. Campos M, Bielefeldt Ohmann H, et al. (1989) Role of interferon- $\gamma$ in inducing cytotoxicity of peripheral blood mononuclear leukocytes to bovine herpesvirus type 1 (BHV-1)-infected cells. Cell. Immunol. 120: 259-269.

106. Hutchings DL, van Drunen Littel-van den Hurk S, Babiuk LA. (1990) Lymphocyte proliferative responses to separate bovine herpesvirus-1 proteins in immune cattle. J. Virol. 64: 5114-5122.

107. Babiuk LA, van Drunen Littel-van den Hurk S, Tikoo SK. (1996) Immunology of bovine herpesvirus 1 infection. Vet. Microbiol. 53: 31-42.

108. Choi S-H, Splitter GA. (1994) Induction of MHCunrestricted cytolytic $\mathrm{CD} 4^{+} \mathrm{T}$ cells against virally infected target cells by cross-linking CD4 molecules. J. Immunol. 153: 3874-3881.

109. Denis M, Slaoui M, Keil G, et al. (1993) Identification of different target glycoproteins for bovine herpesvirus-1 specific cytotoxic T lymphocytes depending on the method of in vitro stimulation. Immunology 78: 7-13.

110. Wang C, Splitter GA. (1998) CD4 ${ }^{+}$cytotoxic Tlymphocyte activity against macrophages pulsed with bovine herpesvirus 1 polypeptides. J. Virol. 72: 7040-7047.

111. Hanon E, Meyer G, Vanderplasschen A, DessyDoize C, Thiry E, Pastoret P-P. (1998) Attachment but not penetration of bovine herpesvirus 1 is necessary to induce apoptosis in target cells. J. Virol. 72: 7638-7641.

112. Ryan AM, Womack JE. (1997) A molecular ge- netic approach to improved animal health. Vet. Clin. North Am: Food Anim. Pract. 13: 401-409.

113. Yu Z, Manickan E, Rouse BT. (1996) Role of interferon- $\gamma$ in immunity to herpes simplex virus. J. Leukoc. Biol. 60: 528-532.

114. Milligan GN, Bernstein DI. (1997) Interferon- $\gamma$ enhances resolution of herpes simplex virus type 2 infection of the murine genital tract. Virology 229: 259-268.

115. Otsuka H, Qavi H, Kit S. (1982) Inhibition by interferon of biochemical transformation induced by cloned herpesvirus thymidine kinase genes. Antiviral Res. 2: 301-311.

116. Hughes HPA, Campos M, Godson DL, van drunen Littel-van den Hurk S, McDougall L, Rapin N. (1991) Immunopotentiation of bovine herpesvirus subunit vaccination by interleukin-2. Immunology 74: 461-466.

117. Reddy PG, Blecha F, Minocha HC, et al. (1989) Bovine recombinant interleukin-2 augment immunity and resistance to bovine herpesvirus infection. Vet. Immunol. Immunopathol. 23: 61-74.

1 18. Hughes HPA, Campos M, van Drunen Littel-van den Hurk S, et al. (1992) Multiple administration with interleukin-2 potentiates antigen-specific responses to subunit vaccination with herpesvirus-1 glycoprotein IV. Vaccine 10: 226-230.

119. Reddy DN, Reddy PG, Minocha HC, et al. (1990) Adjuvancity of recombinant bovine interleukin$1 \beta$ : influence on immunity, infection, and latency in bovine herpesvirus-1 infection. Lymphokine Res. 9: 295-307.

120. Reddy DN, Reddy PG, Xue W, Minocha HC, Daley MJ, Becha F. (1993) Immunopotentiation of bovine respiratory disease virus vaccines by interleukin- $\beta$ and interleukin-2. Vet. Immunol. Immunopathol. 37: 25-38.

121. Baca-Estrada ME, Godson DL, Hughes HPA, et al. (1995) Effect of recombinant bovine interleukin- $1 \beta$ on viral/bacterial pneumonia in cattle. J. Interferon Cytokine Res. 15: 431-439.

122. Leib DA, Olivo PD. (1993) Gene delivery to neurons: is herpes simplex virus the right tool for the job? Bioassays 15: 547-554.

123. Glorioso JC, DeLuca NA, Fink DJ. (1995) Development and application of herpes simplex virus vectors for human gene therapy. Annu. Rev. Microbiol. 49: 675-710.

124. Bello LJ, Whitbeck JC, Lawrence WC. (1992) Bovine herpesvirus 1 as live virus vector for expression of foreign genes. Virology 190: 666-673.

125. Kit M, Kit S, Little SP, Di Marchi RD, Gale C. (1991) Bovine herpesvirus-1 (infectious bovine rhinotracheitis virus) based viral vector which express foot-and-mouth disease epitopes. Vaccine 9: 564-572.

126. Kit S, Otsuka H, Kit M. (1992) Expression of porcine pseudorabies virus genes by a bovine herpesvirus-1 (infectious bovine rhinotracheitis virus) vector. Arch. Virol. 124: 1-20. 
127. Otsuka H, Xuan X. (1996) Construction of bovine herpesvirus-1 (BHV-1) recombinants which express pseudorabies virus (PRV) glycoproteins gB, gC and gE. Arch. Virol. 141: 57-71.

128. Ackermann M, Belak S, Bitsch V, et al. (1990) Round table on infectious bovine rhinotracheitis/infectious postural vulvovaginitis virus infection diagnosis and control. Vet. Microbiol. 23: 361-363.

129. Lemaire M, Schynts F, Meyer G, Thiry E. (1999) Antibody response to glycoprotein $\mathrm{E}$ after bovine herpesvirus type 1 infection in passively immunised, glycoprotein E-negative calves. Vet Rec 144: 172-176.

130. Lemairie M, Meyer G, Ernst E, et al. (1995) Latent bovine herpesvirus 1 infection in calves protected by colostral immunity. Vet. Rec. 137: 70-71.

131. van Oirshot JT, Kaashoek MJ, Rijsewijk FAM. (1996) Advances in the development and evaluation of bovine herpesvirus 1 vaccines. Vet. Microbiol. 53: 43-54.

132. Madin SH, York CJ, McKercher DG. (1956) Isolation of infectious bovine rhinotracheitis virus. Science 124: 721-722.

133. Kendrick JW, York CJ, McKercher DG. (1956) A controlled field trial of a vaccine for infectious bovine rhinotracheitis. Proc. U.S. Livestock San. Assoc. 60: 155-158.

134. Straub OC, Mawhinney IC. (1988) Vaccination to protect calves against infectious bovine rhinotracheitis. Vet. Rec. 122: 407-411.

135. Zygraich N, Lobmann M, Vascoboinic E, Berge E, Huygelen C. (1974) In vivo and in vitro properties of a temperature sensitive mutant in infectious bovine rhinotracheitis virus. Res. Vet. Sci. 16: 328-335.

136. Whetstone CA, Wheeler JG, Reed DE. (1986) Investigation of possible vaccine induced epizootics of infectious rhinotracheitis, using restriction endonuclease analysis of viral DNA. Am. J. Vet. Res. 47: 1789-1795.

137. Whetstone C, Miller J, Bortner D, van Der Maaten MJ. (1989) Changes in the restriction endonuclease patterns of four modified-live infectious bovine rhinotracheitis virus (IBRV) vaccines after one passage in host animal. Vaccine 7: 527-532.

138. Duque $\mathrm{H}$, Marshall $\mathrm{RL}$, Israel BA, Letchworth GJ. (1989) Effect of formalin inactivation on bovine herpesvirus 1 glycoproteins and antibody response elicited by formalin-inactivated vaccines in rabbits. Vaccine 7: 513-520.

139. Brun A, Dauvergine M, Languet B, Reynaud G. (1988) Studies of an inactivated vaccine prepared from viral subunits against infectious bovine rhinotracheitis virus. Med. Vet. 5: 583-586.

140. Frerichs GN, Woods SB, Lucas MH, Sands J-J. (1982) Safety and efficacy of live and inactivated infectious bovine rhinotracheitis vaccines. Vet. Rec. 111: 116-122.

141. Bryan LA, Fenton RA, Misra V, Haines DM. (1994) Fatal, generalized bovine herpesvirus type 1 infection associated with a modified-live infectious bovine rhinotracheitis parainfluenza-3 vaccine administered to neonatal calves. Can. Vet. J. 35: 223-228.

142. Backer JC, Rust RS, Walker RD. (1989) Transmission of a vaccinal strain of infectious bovine rhinotracheitis virus from intranasally vaccinated steers commingled with non vaccinated steers. Am. J. Vet. Res. 50: 814-816.

143. Pastoret P-P, Babiuk LA, Misra V, Griebel P. (1980) Reactivation of temperature-sensitive and non-temperature sensitive infectious bovine rhinotracheitis vaccine virus with dexamethasone. Infect. Immunol. 29: 483-488.

144. George LW, Ardans A, Mihalyi S, Guerra MR. (1988) Enhancement of infectious bovine keratoconjunctivitis by modified-live infectious bovine rhinotracheitis virus vaccine. Am. J. Vet. Res. 49: $1800-1806$.

145. Kelling CL, Schipper IA, Strum GE, Carlson RB, Tilton GE. (1973) Infectious bovine rhinotracheitis (IBR) abortion; observations on incidence in vaccinated and non-vaccinated and exposed cattle. Cornell Vet. 63: 383-389.

146. van Der Maaten MJ, Miller JM, Whetstone CA. (1985) Ovarian lesions induced in heifers by intravenous inoculation with modified-live infectious bovine rhinotracheitis virus on the day after breeding. Am. J. Vet. Res. 46: 1996-1999.

147. Smith PC, Nusbaum KE, Kwapien RP, Stringfellow DA, Driggers K. (1990) Necrotic oophoritis in heifers vaccinated intravenously with infectious bovine rhinotracheitis virus vaccine during estrus. Am. J. Vet. Res. 51: 969-972.

148. Harasawa R. (1995) Advention pestivirus RNA in live virus vaccine against bovine and swine diseases. Vaccine 13: 100-103.

149. Babiuk LA, L'Italien J, van Drunen Littel-van den Hurk S, et al. (1987) Protection of cattle from bovine herpesvirus type-1 (BHV-1) infection by immunization with individual glycoproteins. Virology 159: 57-66.

150. Van Drunen Littel-van den Hurk S, van Den Hurk JV, Gilchrist JE, Misra V, Babiuk LA. (1984) Interactions of monoclonal antibodies and bovine herpesvirus type l (BHV-1) glycoproteins: characterization of their biochemical and immunological properties. Virology 135: 466-479.

151. Collins JK, Butcher AC, Riegel CA. (1985) Immune response to bovine herpesvirus type-1 infections: virus-specific antibodies in sera from infected animals. J. Clin. Microbiol. 21: 546-552.

152. Ayers VK, Collins JK, Purdy CW. (1994) Epitope-specific antibody responses in market- 
stressed calves to bovine herpesvirus type 1. Vaccine 12: 940-946.

153. Israel BA, Marshall RL, Letchworth GL. (1988) Epitope specificity and protective efficacy of the bovine immune response to bovine herpesvirus-1 glycoprotein vaccine. Vaccine 6: 349-356.

154. Kaashoek MJ, Moerman A, Madic J, et al. (1995) An inactivated vaccine based on a glycoprotein gE-negative strain of bovine herpesvirus 1 induces protective immunity and allows serological differentiation. Vaccine 13: 342-346.

155. Zhu X, Letchworth GJ. (1996) Mucosal and systemic immunity to bovine herpesvirus-1 glycoprotein D confer resistance to viral replication and latency in cattle. Vaccine 14: 61-69.

156. Babiuk LA, van Drunen Littel-van den Hurk S, Tikoo SK, Lewis PJ, Liang X. (1996) Novel viral vaccines for livestock. Vet. Immunol. Immunopathol. 54: 355-363.

157. Fitzpatrick DR, Zamb T, Parker MD, van Drunen Littel-van den Hurk S, Babiuk LA, Lawman MJP. (1988) Expression of bovine herpesvirus 1 glycoproteins gI and gIII in transfected murine cells. J. Virol. 62: 4239-4248.

158. van Drunen Littel-van den Hurk S, Zamb TJ, Babiuk LA. (1989) Synthesis, cellular location and immunogenicity of bovine herpesvirus-1 glycoproteins gI and gIII expressed by recombinant vaccinia virus. J. Virol. 63: 2159-2168.

159. Leary TP, Gao Y, Splitter GA. (1992) Constitutively expressing cell lines which secrete bovine herpesvirus- 1 glycoprotein I stimulate T lymphocyte responsiveness. Immunology 76: 367-372.

160. van Drunen Littel-van den Hurk S, Parker MD, Massie B, van den Hurk JV, Harland R, Babiuk LA. (1993) Protection of cattle from BHV-1 infection by immunization with recombinant glycoprotein gIV. Vaccine 11: 25-36.

161. van Drunen Littel-van den Hurk S, Parker MD, Fitzpatrick DR, et al. (1991) Expression of bovine herpesvirus 1 glycoprotein gIV by recombinant baculovirus and analysis of its immunogenic properties. J. Virol. 65: 263-271.

162. van Drunen Littel-van den Hurk S, van Donkersgoed J, Kowalski J, et al. (1994) A subunit gIV vaccine produced by transfected mammalian cells in culture, induces mucosa immunity against bovine herpesvirus-1 in cattle. Vaccine 12: 1295-1302.

163. Merza M, Tibor S, Kucsera L, Bognar G, Morein B. (1991) ISCOM of BHV-1 envelope glycoproteins protected calves against both disease and infection. J. Vet. Med. 38: 306-314.

164. Garcia-Valcarcel M, Fowler WJ, Harper DR, Jeffries DJ, Layton GT. (1997) Cloning, expression and immunogenicity of the assembly protein of varicella-zoster virus and detection of the products of open reading frame 33. J. Med. Virol. 53: 332-339.

165. Trudel M, Nadon F, Seguin C, Boulay G, Lussier
G. (1987) Vaccination of rabbits with a bovine herpesvirus type 1 subunit vaccine: adjuvant effect of ISCOMs. Vaccine 5: 239-243.

166. Moser CA, Speaker TJ, Offit PA. (1997) Effect of microencapsulation on immunogenicity of a bovine herpes virus glycoprotein and inactivated influenza virus in mice. Vaccine 15: 1767-1772.

167. Young PL, Smith GA. (1995) Genetically altered herpesviruses as vaccines. Vet. Microbiol. 46: 175179.

168. Rijsewijk FAM, Kaashoek MJ, Keil G, et al. (1994) In vitro and in vivo phenotypes and immunogenic properties of bovine herpesvirus 1 mutants with a deletion in the gC, gG, gI or gE gene. In: Proceedings of the 19th Herpesvirus Workshop, Vancouver, July 30-August 5, p. 419.

169. Kit S, Qavi H, Gaines JD, Billingsley P, McConnell S. (1985) Thymidine kinase-negative bovine herpesvirus type 1 mutant is stable and highly attenuated in calves. Arch. Virol. 86: 63-83.

170. Smith GA, Young PL, Rodwell BJ, et al. (1994) Development and trial of a bovine herpesvirusl-thymidine kinase deletion virus as a vaccine. Austr. Vet. J. 71: 65-70.

171. Yu-Su K, Liu C, Manning J-RS. (1986) Identification of the thymidine kinase gene of infectious bovine rhinotracheitis virus and its function in Escherichia coli hosts. Gene 44: 279-285.

172. Bello L, Whitbeck JC, Lawrence WC. (1987) Map location of the thymidine kinase gene of bovine herpesvirus 1. J. Virol. 61: 4023-4025.

173. Kaashoek MJ, Moerman A, Madic J, et al. (1994) A conventionally attenuated glycoprotein E-negative strain of bovine herpesvirus type 1 is an efficacious and safe vaccine. Vaccine 12: 439444.

174. van Oirschot JT. (1994) Vaccination in food animal population. Vaccine 12: 415-418.

175. Kaashoek MJ, van Engelenburg FAC, Moerman A, Gielkens ALJ, Rijsewijk FAM, van Oirschot JT. (1996) Virulence and immunogenicity in calves of thymidine kinase- and glycoprotein Enegative bovine herpesvirus 1 mutants. Vet. Microbiol. 48: 143-153.

176. Flores EF, Osorio FA, Zanella EL, Kits S, Kit M. (1993) Efficacy of a deletion mutant bovine herpesvirus-1 (BHV-1) vaccine that allows serologic differentiation of vaccinated from naturally infected animals. J. Vet. Diagn. Invest. 5: 534-540.

177. Bosch JC, Frankena K, van Oirschot JT. (1996) Effect on milk production of vaccination with a bovine herpesvirus 1 gene-deleted inactivated vaccine. Vet. Rec. 140: 196-199.

178. Strube W, Auer S, Block W, et al. (1996) A gE deleted infectious bovine rhinotracheitis marker vaccine for use in improved bovine herpesvirus 1 control programs. Vet. Microbiol. 53: 181-189.

179. Denis M, Hanon E, Rijsewijk FAM, et al. (1996) The role of glycoproteins $\mathrm{gC}, \mathrm{gE}, \mathrm{gI}$ and $\mathrm{gG}$ in the 
induction of cell-mediated immune responses to bovine herpesvirus 1. Vet. Microbiol. 53: 121-132.

180. Chowdhury SI. (1996) Construction and characterization of an attenuated bovine herpesvirus type 1 (BHV-1) recombinant virus. Vet. Microbiol. 52: 13-23.

181. Kuhnle G, Collins RA, Scott JE, Keil M. (1996) Bovine interleukins 2 and 4 expressed in recombinant bovine herpesvirus 1 are biologically active secreted glycoproteins. J. Gen. Virol. 77: 2231-2240.

182. Dinarello CA. (1991) Interleukin-1 and interleukin-1 antagonism. Blood 77: 1627-1652.

183. Raggo C, Fitzpatrick DR, Babiuk LA, Liang X. (1996) Expression of bovine interleukin-1 $\beta$ in a bovine herpesvirus-1 vector: in vitro analysis. Virology 221: 78-86.

184. Cox GJM, Zamb TJ, Babiuk LA. (1993) Bovine herpesvirus 1: immune responses in mice and cattle injected with plasmid DNA. J. Virol. 67: 5664-5667.

185. Terpstra C, Kroese AH. (1996) Potency control of modified live vaccines for veterinary use. Vaccine 14: 13-18.

186. Strube W, Abar B, Bergle RD, et al. (1995) Safety aspects in the development of an infectious bovine rhinotracheitis marker vaccine. Dev. Biol. Stand. 84: 75-81.

187. Mettenleiter TC. (1996) Conclusions from the symposium. Vet. Microbiol. 53: 207-211.

188. van Drunen Littel-van den Hurk S, Khattar S, Tikoo SK, et al. (1996) Glycoprotein H (gII/ gp 108) and glycoprotein L form a functional complex which plays a role in penetration, but not in attachment, of bovine herpesvirus 1 . J. Gen. Virol. 77: 1515-1520.
189. Baranowski E, Dubuisson J, van Drunen Littelvan den Hurk S, et al. (1995) Synthesis and processing of bovine herpesvirus-1 glycoprotein H. Virology 206: 651-654.

190. Chowdhury SI. (1997) Fine mapping of bovine herpesvirus 1 (BHV-1) glycoprotein C neutralizing epitopes by type-specific monoclonal antibodies and synthetic peptides. Vet. Microbiol. 58: 309-314.

191. Keil GM, Engelhardt T, Karger A, Enz M. (1996) Bovine herpesvirus $1 \mathrm{U}_{\mathrm{S}}$ open reading frame 4 encodes a glycoproteoglycan. J. Virol. 70: 30323038.

192. Kuhnle G, Heinze A, Schmitt J, et al. (1998) The class II membrane glycoprotein $\mathrm{G}$ of bovine respiratory syncytial virus, expressed from a synthetic open reading frame, is incorporated into virions of recombinant bovine herpesvirus 1 . J. Virol. 72: 3804-3811.

193. Khadr A, Tikoo SK, Babiuk LA, van Drunen Littel-van den Hurk S. (1996) Sequence and expression of a bovine herpesvirus-1 gene homologous to the glycoprotein $\mathrm{K}$-encoding gene of herpes simplex virus-1. Gene 168: 189-193.

194. Wu SX, Zhu XP, Letchworth GJ. (1998) Bovine herpesvirus 1 glycoprotein $\mathrm{M}$ forms a disulfidelinked heterodimer with the UL 49.5 protein. J. Virol. 72: 3029-3036.

195. Khattar SK, van Drunen Littel-van den Hurk S, Attah-Poku SK, Babiuk LA, Tikoo SK. (1996) Identification and characterization of a bovine herpesvirus-1 (BHV-1) glycoprotein gL which is required for proper antigenicity, processing, and transport of BHV-1 glycoprotein gH. Virology 219: 66-76. 